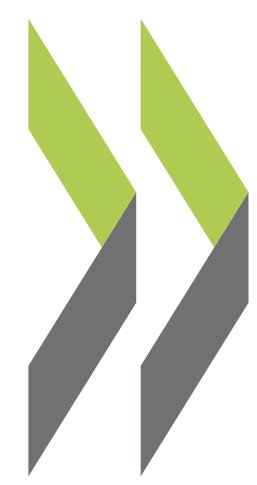

OECD Economics Department Working Papers No. 399

Product Market Competition and Economic Performance

in Korea

\section{Yongchun Baek,}

Randall S. Jones,

Michael Wise 
PRODUCT MARKET COMPETITION AND ECONOMIC PERFORMANCE IN KOREA ECONOMICS DEPARTMENT WORKING PAPIERS No. 399

by

Yongchun Baek, Randall Jones and Michael Wise

All Economics Department Working Papers are now available online through the OECD's website at: http://www.oecd.org/eco 


\section{ABSTRACT/RESUMÉ \\ PRODUCT MARKET COMPETITION AND ECONOMIC PERFORMANCE IN KOREA}

Maintaining rapid economic growth depends increasingly on productivity gains, particularly in the service sector. Competition has an important role to play in achieving such gains. However, Korea's development strategy has tended to weaken competition and has left a legacy of government intervention. Strengthening competition requires upgrading competition policy, increasing openness to international trade and foreign direct investment and improving the regulatory framework in network industries. In particular, the power of the Korea Fair Trade Commission should be expanded, while raising the level of sanctions and scaling back special treatment for certain sectors. Barriers to imports remain above the OECD average, particularly in agriculture, while the stock of inward direct investment is among the lowest in the OECD area. Restructuring plans in the network industries, notably electricity and gas, have lagged behind schedule. Price distortions and the absence of independent sectoral regulators hamper efforts to strengthen competition in network industries. In the retail sector, entry barriers make it difficult to establish large retail outlets. The paper concludes that actions in a number of areas are needed to strengthen competition, thereby sustaining rapid growth and promoting Korea's convergence to the income levels in the most advanced OECD countries.

Key words: Korea, South Korean economy, anti-trust law, competition law, cartel, regulatory reform, retail sector, network industries, telecommunications, electricity, gas, foreign direct investment, tariffs, trade policy, chaebol.

JEL codes: F13, F21, K21, L11, L40, L43, L81, L94, L95, L96, O53, O57, Q17.

\section{CONCURRENCE SUR LES MARCHÉS DE PRODUITS ET PERFORMANCES ÉCONOMIQUES EN CORÉE}

Le maintien d'une croissance économique rapide est de plus en plus tributaire des gains de productivité, en particulier dans le secteur des services. La concurrence a un rôle important à jouer dans la réalisation de ces gains. Néanmoins, la stratégie de développement de la Corée a eu tendance à affaiblir la concurrence et se traduit par une politique interventionniste héritée du passé. Le renforcement de la concurrence passe par une rénovation de la politique de la concurrence, une ouverture accrue aux échanges internationaux ainsi qu'à l'investissement direct étranger (IDE), et une amélioration du cadre réglementaire dans les industries de réseau. Il conviendrait de renforcer les prérogatives de la Commission coréenne de la concurrence, tout en alourdissant les sanctions prévues par la loi et en revoyant à la baisse les dispositions spéciales prévues pour certains secteurs. Les obstacles aux importations demeurent supérieurs à la moyenne de l'OCDE, notamment dans l'agriculture, tandis que le stock d'IDE est un des plus faibles de la zone OCDE. La mise en œuvre des programmes de restructuration des industries de réseaux, notamment dans le domaine de l'électricité et du gaz, a pris du retard. Des distorsions de prix et l'absence d'organismes sectoriels de réglementation indépendants entravent les efforts déployés pour renforcer la concurrence dans les industries de réseau. Dans le secteur de la distribution, des barrières à l'entrée font obstacle à l'ouverture de grandes surfaces. En conclusion, le document de travail souligne que des mesures s'imposent dans un certain nombre de domaines pour renforcer la concurrence, ce qui permettra de maintenir un rythme rapide d'expansion économique et de favoriser la convergence de la Corée vers les niveaux de revenu des pays les plus avancés de l'OCDE.

Mots-clés : Corée, économie sud-coréenne, législation antitrust, droit de la concurrence, entente, réforme de la réglementation, commerce de détail, industries de réseau, télécommunications, électricité, gaz, investissement direct étranger, tarifs douaniers, politique commerciale, chaebol.

Codes JEL : F13, F21, K21, L11, L40, L43, L81, L94, L95, L96, O53, O57, Q17.

Copyright : OECD 2004

Application for permission to reproduce or translate all, or part of, this material should be made to: Head of Publication Service, OECD, 2, rue André Pascal, 75775 Paris Cedex 16, France. 
TABLE OF CONTENTS

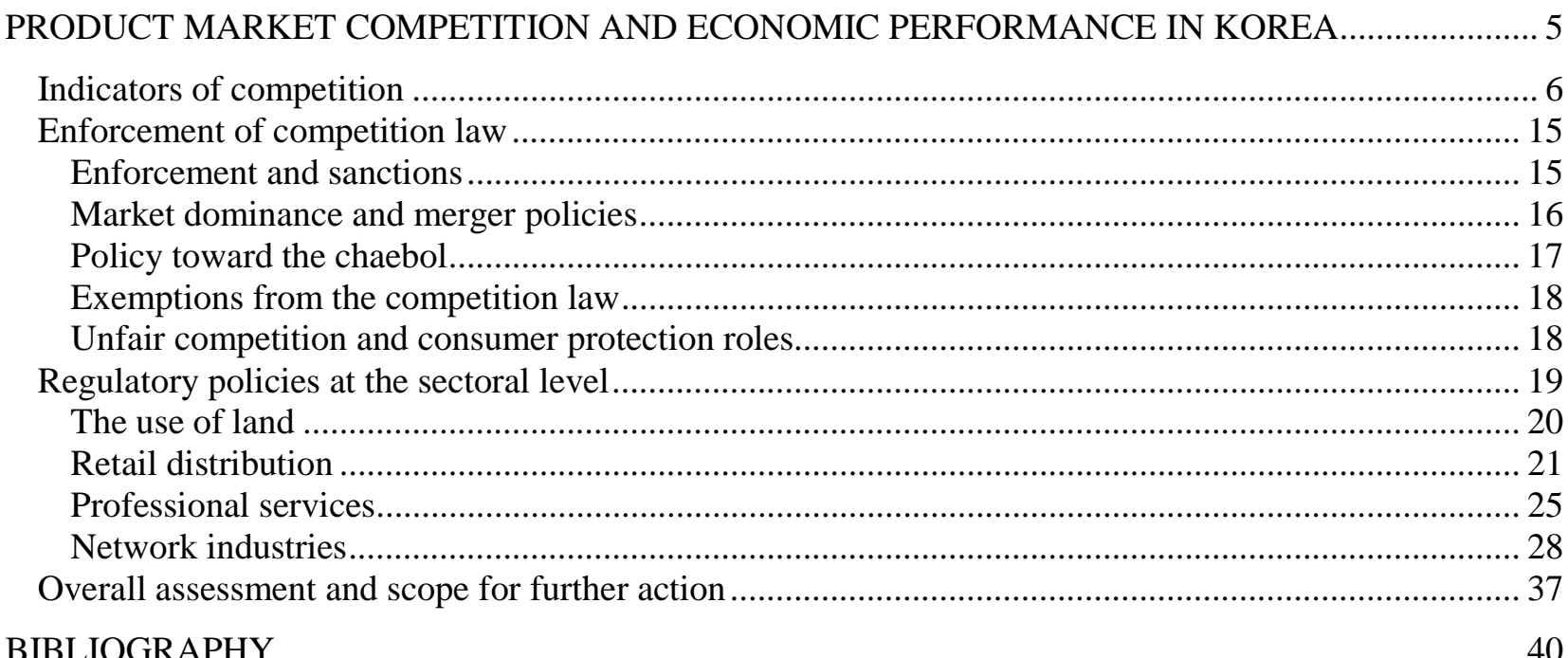

\section{Tables}

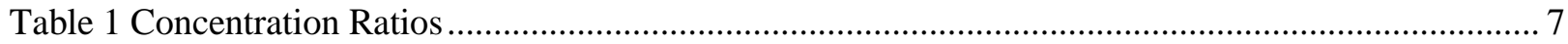

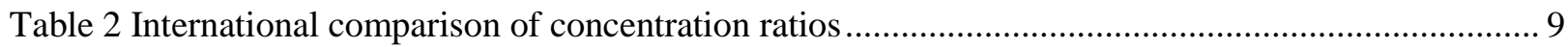

Table 3 International comparison of import penetration by type of manufacturing industry .................. 10

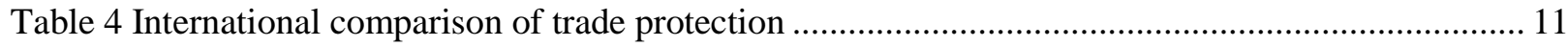

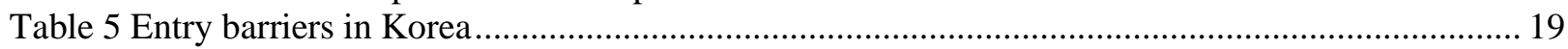

Table 6 Key structural features of the retail distribution sector ......................................................... 22

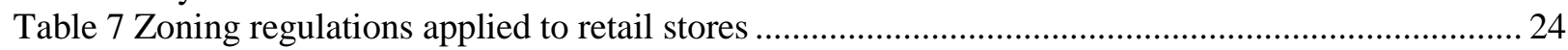

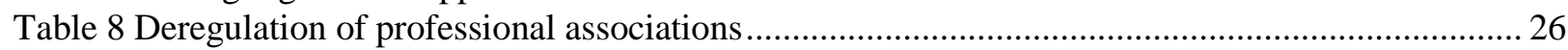

Table 9 Number of entrants per year in the selected professional services........................................... 28

Table 10 The original plan for reforming the electricity sector ............................................................. 31

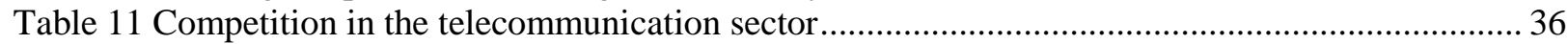

\section{Boxes}

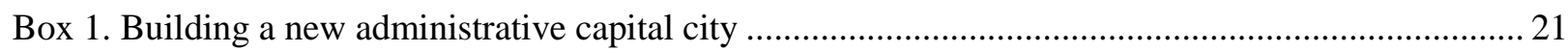

Box 2. Summary of recommendations to strengthen competition .......................................................... 38 


\section{ECO/WKP(2004)22}

\section{Figures}

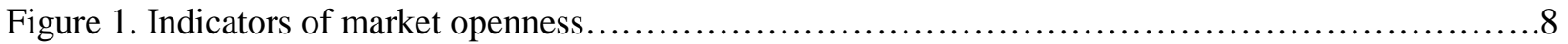

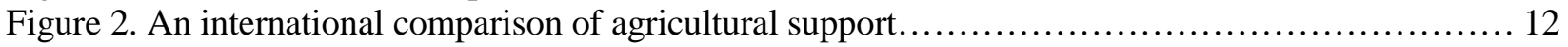

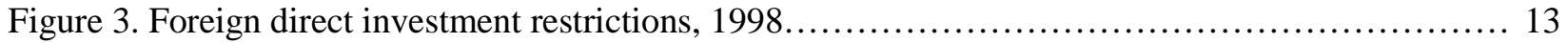

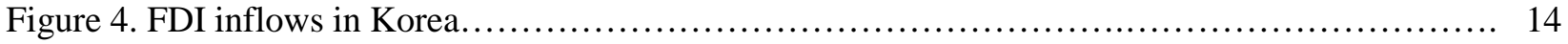

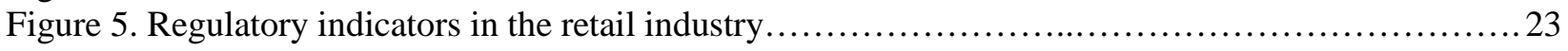

Figure 6. Regulations of professions: restrictiveness indices for OECD countries...................25

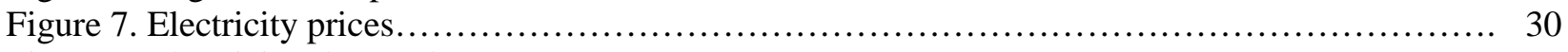

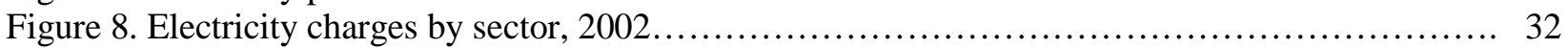

Figure 9. Telecommunication charges in the OECD........................................... 35 
ECO/WKP(2004)22

\section{PRODUCT MARKET COMPETITION AND ECONOMIC PERFORMANCE IN KOREA By Yongchun Baek, Randall Jones and Michael Wise ${ }^{1}$}

1. The OECD Growth Study and other empirical work demonstrate that competition in product markets plays a significant role in the process of economic growth. Korea has succeeded in transforming itself from one of the poorest countries in the world in the 1960s to an important industrial nation over the period of one generation. This has been accomplished despite government measures over the past forty years to accelerate growth, focusing on export-oriented manufacturing industries in which scale economies are important, which tended to weaken competition to some extent. The outstanding economic performance suggests that there may have been some positive results from these policies, perhaps because they enabled Korea to overcome various negative externalities prevalent at an early stage of development. However, they have also left a negative legacy that includes distortions in resource allocation, high concentration in product markets, barriers to entry and exit, an important role for trade associations, government ownership, and the formation of business conglomerates, called chaebol. Moreover, the development strategy resulted in a dualistic economy, divided between highly competitive, export-oriented manufacturing and a much less dynamic, domestic demand-oriented sector. Indeed, the productivity gap between the manufacturing and service sectors in Korea is the largest in the OECD area. These various negative factors may prove detrimental to Korea's growth prospects, which are likely to be increasingly linked to a knowledge-based economy.

2. Korea's labour productivity (per hour worked) was about half of the OECD average in 2002, suggesting considerable scope for further convergence. Inputs of labour and capital have played a key role in its economic development, while total factor productivity has accounted for less than one-third of growth. However, slowing inputs of labour and capital during the coming decade, reflecting declining working hours and the falling trend of business investment, may significantly reduce the growth potential. According to one study, the contribution to growth from labour and capital inputs will fall by half from $4 \frac{1}{2}$ percentage points a year in the 1990s to $2 \frac{1}{4}$ in the coming decade (Han et al., 2002). Economic growth will thus depend increasingly on total factor productivity gains. Structural reforms, including measures to strengthen product market competition, are essential to realising such gains and sustaining Korea's growth potential. This is particularly true in the service sector, where competition is relatively weak at present and productivity is low, due in part to the fact that it is less exposed to international competition. The authorities have introduced measures aimed at strengthening market forces, although the legacy of past policies is difficult to dismantle and progress has been uneven.

3. This paper begins by presenting some indicators to gauge the strength of competitive pressures, as well as the implications of barriers to trade and foreign direct investment. This is followed by an overall assessment of the competition policy framework and its role in promoting competition. The paper then

1. This paper was originally prepared for the 2004 OECD Economic Survey of Korea published in June 2004 under the authority of the Economic and Development Review Committee of the OECD. Yongchun Baek is an economist on the Japan/Korea Desk in the OECD's Economics Department and Randall Jones is head of that Desk. Michael Wise is a lawyer in the Competition Division of the OECD's Directorate for Financial and Enterprise Affairs. They wish to thank Jørgen Elmeskov, Jens Høj, Val Koromzay, Andrew Dean, Willi Leibfritz and other colleagues in the OECD Economics Department for useful comments. This paper has benefited from the statistical assistance of Brooke Malkin and the secretarial assistance of Nadine Dufour in preparing the document. 
analyses a number of sectors where policies to strengthen competition can be expected to have particularly large benefits. The paper concludes with a set of policy recommendations.

\section{Indicators of competition}

4. Although measuring the extent of competition is not straightforward, it is useful to examine available indicators that may convey some information on the strength of competitive forces. Available indicators include concentration ratios, price mark-ups and barriers to trade and investment. While these indicators suggest that competition has strengthened gradually over the past twenty years, the degree of competition may still be weak relative to other countries.

5. The concentration ratios show several interesting trends (Table 1). First, ratios at the industry level (Panel A) and the market level (Panel B) have been declining since the 1980s, suggesting that the economy is moving toward a more competitive structure. ${ }^{2}$ However, the downward trend was temporarily reversed in the wake of the 1997 crisis, reflecting the exit of non-viable companies or their merger with stronger firms. ${ }^{3}$ Second, the general concentration ratio (Panel C), measured as the shares of the largest 50 and 100 firms in terms of turnover and employment, has also fallen significantly since the crisis. Third, concentration diminishes as market size increases (Panel D). However, for markets larger than 1 trillion won, concentration goes up instead, reflecting the importance of economies of scale in leading industries, such as semiconductors and cars, and the fact that the high level of initial investment required acts as an entry barrier. ${ }^{4}$ However, these highly concentrated industries are part of a larger competitive global market.

6. International comparisons of concentration show that the average share of the three largest firms in Korea is comparable to those in Japan and the United States (Table 1, Panel E). However, compared to the latter two countries, the HHI shows a significantly higher degree of concentration in Korea. ${ }^{5}$ The HHI in "segmented" industries, which are characterised by large firms and significant entry barriers, is particularly high in Korea (Table 2).

2. Industry concentration is based on the 491 industries in the Korean Standard Industrial Classification (KSIC) 5-digit categorisation, while market concentration is based on the 3056 markets in the KSIC's 8-digit categorisation. The degree of concentration in each is measured by the combined market share of the top three firms and by the Hirschman-Herfindahl Index (HHI). The Monopoly Regulation and Fair Trade Act (MRFTA) defines a concentrated industry or market as one in which the top firm has a market share of more than 50 per cent or in which the top three firms have a combined share of more than 75 per cent.

3. However, the weighted averages of the concentration ratios and the HHI measure have fallen less than the simple averages and in some cases have risen since the crisis. This reflects the fact that growth in recent years has been driven by the ICT sector, which has become more concentrated. It is also due to the business swaps, the so-called "Big Deals", which were implemented following the crisis in an effort to reduce excess capacity and high debt to equity ratios (see the 1999 OECD Economic Survey of Korea). The Big Deals covered major industries such as semiconductors, power-generating equipment, petrochemicals, aerospace, railroad vehicles, ship engines and oil refinery. For example, LG Semiconductor was combined with Hyundai Electronics, and later re-named Hynix Semiconductor.

4. The market share of the three largest companies in major industries in 2001 was 92.0 per cent for cars, 88.0 per cent for electronic integrated circuits, 78.5 per cent for ships, 78.1 per cent for petroleum refineries and 70.6 per cent for communication and radio/television broadcasting equipment. This was considerably above the simple average of 43.4 per cent in the manufacturing and mining sectors and the weighted average of 51.5 per cent.

5. Comparisons of HHI are limited by the fact that data are only available for nine OECD countries. Moreover, the HHI is based on firm-level data, except in Korea, Japan and the United States, where it is based on establishment data. 
Table 1. Concentration ratios

A. Industry concentration ratios

\begin{tabular}{|c|c|c|c|c|c|c|c|c|}
\hline & & 1980 & 1990 & 1997 & 1998 & 1999 & 2000 & 2001 \\
\hline \multicolumn{9}{|l|}{ Share of top 3 firms (per cent) } \\
\hline Simple average & & 62.4 & 52.8 & 48.6 & 50.0 & 45.4 & 44.0 & 43.4 \\
\hline Weighted average & & 55.1 & 52.6 & 51.7 & 53.6 & 54.2 & 52.5 & 51.5 \\
\hline \multicolumn{9}{|l|}{$\mathrm{HHI} \times 1000^{1}$} \\
\hline Simple average & & 263.8 & 221.3 & 179.4 & 190.5 & 158.6 & 152.5 & 153.1 \\
\hline Weighted average & & 180.6 & 187.8 & 177.8 & 188.0 & 194.5 & 183.5 & 182.1 \\
\hline \multicolumn{9}{|c|}{ B. Market concentration ratios } \\
\hline & & 1980 & 1990 & 1997 & 1998 & 1999 & 2000 & 2001 \\
\hline \multicolumn{9}{|l|}{ Share of top 3 firms (per cent) } \\
\hline Simple average & & 81.7 & 73.9 & 73.1 & 73.0 & 72.5 & 69.9 & 68.0 \\
\hline Weighted average & & 67.1 & 62.6 & 65.4 & 67.3 & 67.1 & 65.6 & 64.0 \\
\hline \multicolumn{9}{|l|}{$\mathrm{HHI} \times 1000^{1}$} \\
\hline Simple average & & 473 & 393 & 388 & 388 & 389 & 357 & 331 \\
\hline Weighted average & & 288 & 262 & 283 & 289 & 295 & 285 & 267 \\
\hline \multicolumn{9}{|c|}{ C. General concentration ratios (per cent) } \\
\hline & & 1980 & 1990 & 1997 & 1998 & 1999 & 2000 & 2001 \\
\hline \multicolumn{9}{|l|}{ Turnover: } \\
\hline 50 largest enterprises & & 30.0 & 30.0 & 37.1 & 38.4 & 38.0 & 38.1 & 36.8 \\
\hline 100 largest enterprises & & 39.0 & 37.3 & 44.2 & 45.9 & 45.1 & 44.8 & 43.7 \\
\hline \multicolumn{9}{|l|}{ Employment: } \\
\hline 50 largest enterprises & & 13.3 & 13.6 & 16.5 & 16.6 & 14.7 & 13.9 & 13.2 \\
\hline 100 largest enterprises & & 18.6 & 18.4 & 20.1 & 20.1 & 18.1 & 17.0 & 16.0 \\
\hline \multicolumn{9}{|c|}{ D. Industry concentration ratio by market size } \\
\hline Size (billion won) & $\begin{array}{l}\text { Less } \\
\text { than } 1\end{array}$ & $1-10$ & $10-50$ & $50-100$ & $100-500$ & $\begin{array}{l}500- \\
1000\end{array}$ & $\begin{array}{l}1000- \\
5000\end{array}$ & $\begin{array}{c}\text { Higher } \\
\text { than } \\
5000\end{array}$ \\
\hline Number of Industries & 2 & 18 & 42 & 34 & 179 & 92 & 96 & 21 \\
\hline Total turnover (billion won) & 10 & 926 & 11354 & 26021 & 470057 & 646040 & 2055946 & 2640110 \\
\hline Share of top 3 firms (per cent) & 100 & 80 & 52 & 49 & 37 & 37 & 39 & 68 \\
\hline $\mathrm{HHI} \times 1000^{1}$ & 674 & 483 & 182 & 155 & 121 & 105 & 127 & 255 \\
\hline
\end{tabular}

E. International Comparisons

\begin{tabular}{lcc}
\hline Market Concentration & Japan (2000) & Korea (2001) \\
\cline { 2 - 3 } Top 3 firms (per cent, simple average) & 72.0 & 68.0 \\
HHI x 1 000 (simple average) & 269.3 & 331.0 \\
\hline & & \\
\hline Industry concentration & US (1997) & Korea (2001) \\
\cline { 2 - 3 } Top 4 firms (per cent, simple average) & 42.8 & 48.6 \\
HHI x 1 000 (simple average) & 75.8 & 149.3 \\
\hline
\end{tabular}

1. The Hirschman-Herfindahl Index combines elements of both firm numbers and inequality. For an industry with $\mathrm{N}$ firms, it can be defined as:

$H H I=\sum_{i=1}^{N}\left[\frac{X_{i}}{\sum_{i} X_{i}}\right]^{2}$

where $\mathrm{i}$ indexes firms $1,2, \ldots, \mathrm{N}$ and $\mathrm{X}$ is an appropriate measure of firm size (e.g. gross output). When an industry is occupied by only one firm (a pure monopolist), the index attains its maximum value of 1 (1000 in this table since the index is multiplied by 1000$)$.

Source: Korea Fair Trade Commission and Korea Development Institute. 
7. Industries with high market concentration ratios show significantly higher price mark-ups according to one study (Jeong et al., 2002). Moreover, the relationship becomes more powerful as firms' export ratio (export/shipment) increases, which may indicate that exporting companies have a relatively high degree of dominance in domestic markets. As for R\&D expenditures, there is a weak positive correlation with industry concentration ratios. However, in monopolistic market structures, R\&D expenditures fell. This suggests that, beyond a certain point, market power tends to reduce incentives to adopt and develop new technology, thus discouraging dynamic efficiency gains.

Figure 1. Indicators of market openness
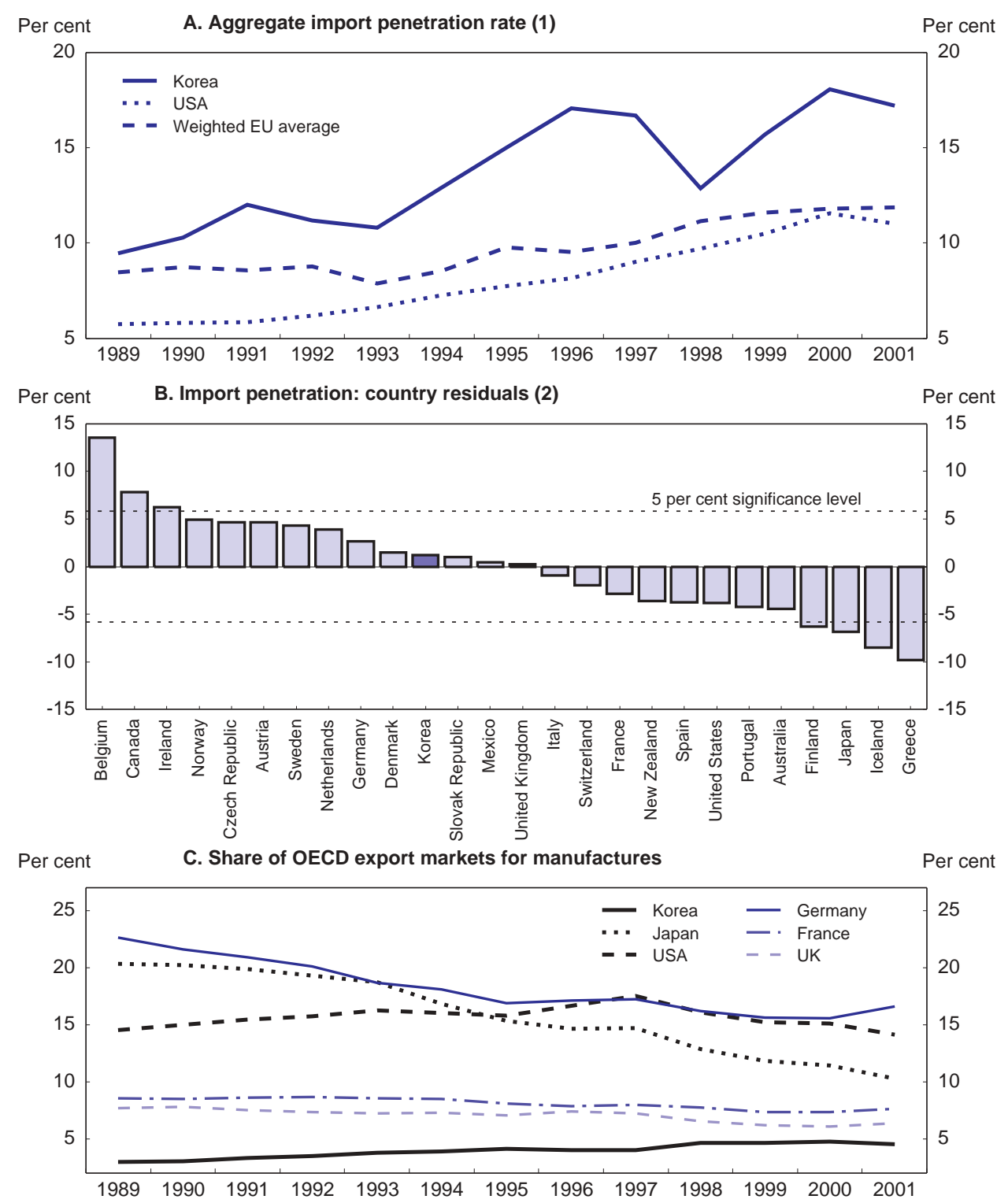

1. Manufacturing imports relative to manufacturing imports plus GDP, excluding intra-EU trade.

2. Average residuals over the period 1995 to 2000 after controlling for effects of country size, GDP per capita and transportation costs.

Source: OECD, Monthly Trade Statistics and OECD calculations. 
8. Import penetration has risen from around 10 per cent at the beginning of the 1990s to 17 per cent a decade later (Figure 1). The rate in Korea is in line with those in other OECD countries after controlling for country size, per capita income and transportation costs (Panel B). However, a breakdown by type of

Table 2. International comparison of concentration ratios ${ }^{1}$

Based on establishment data ${ }^{2}$

\begin{tabular}{|c|c|c|c|}
\hline & Korea & Japan & United States \\
\hline & 1997 & 1999 & 1997 \\
\hline \multicolumn{4}{|l|}{$\begin{array}{l}\text { MANUFACTURING } \\
\text { Fragmented, low R\&D }\end{array}$} \\
\hline Food products & 18.8 & 1.5 & 3.3 \\
\hline Textiles & 12.0 & 3.3 & 6.5 \\
\hline Wearing apparel & 73.0 & 4.0 & 8.6 \\
\hline Leather products & 86.2 & 45.6 & 65.1 \\
\hline Footwear & 72.2 & 32.1 & n.a. \\
\hline Wood products & 109.2 & 5.0 & 3.7 \\
\hline Paper and pulp products & 76.1 & 23.0 & 14.4 \\
\hline Publishing and printing & 60.9 & 17.9 & 3.0 \\
\hline Plastic products & 50.7 & 6.8 & 5.0 \\
\hline Non-metallic products & 29.3 & 8.8 & 6.6 \\
\hline Fabricated metal products & 232.7 & 9.9 & 1.6 \\
\hline Furniture & 70.6 & 13.2 & 7.6 \\
\hline Unweighted average & 74.3 & 14.3 & 11.4 \\
\hline \multicolumn{4}{|l|}{ Segmented, low R\&D } \\
\hline Beverages & 177.8 & 39.8 & 191.5 \\
\hline Tobacco products & 1225.5 & 386.4 & n.a. \\
\hline Refined petroleum products & 1988.9 & 236.9 & n.a. \\
\hline Rubber products & 490.3 & 75.3 & n.a. \\
\hline Glass products & 377.3 & 105.2 & n.a. \\
\hline Basic metals & 195.5 & 46.4 & 29.0 \\
\hline Iron and steel & 344.5 & 71.8 & n.a. \\
\hline Non-ferrous metals & 293.0 & 64.9 & n.a. \\
\hline Shipbuilding and repairs & 1096.9 & 178.4 & n.a. \\
\hline Unweighted average & 687.7 & 133.9 & 110.3 \\
\hline \multicolumn{4}{|l|}{ Fragmented, high R\&D } \\
\hline Machinery and equipment & 42.5 & 7.5 & 7.5 \\
\hline Medical appliances & 112.4 & 47.7 & n.a. \\
\hline Other manufacturing & 45.7 & 34.2 & 11.1 \\
\hline Unweighted average & 66.9 & 29.8 & 9.3 \\
\hline \multicolumn{4}{|l|}{ Segmented, high R\&D } \\
\hline Coke and petroleum products & 1919.1 & 220.1 & 76.4 \\
\hline Chemicals products & 54.3 & 14.9 & 14.4 \\
\hline Drugs and medicines & 91.8 & 50.9 & n.a. \\
\hline Office \& computing machinery & 1301.8 & 84.2 & 17.9 \\
\hline Electrical machinery & 51.6 & 21.6 & 13.9 \\
\hline Radio, TV and communication equipment & 144.6 & 18.6 & n.a. \\
\hline Optical and photographic equipment & 1919.5 & 137.9 & n.a. \\
\hline Watches and clocks & 762.9 & 1173.9 & n.a. \\
\hline Motor vehicles & 226.7 & 49.4 & 23.9 \\
\hline Other transport equipment & 585.3 & 109.2 & n.a. \\
\hline Railroad equipment & 3305.3 & 805.0 & n.a. \\
\hline Aircraft & 2675.8 & 593.1 & n.a. \\
\hline Unweighted average & 1086.6 & 273.2 & 12.2 \\
\hline
\end{tabular}

1. The Hirschman-Herfindahl Index * 10000 .

2. No data is available for Korea for the non-manufacturing sector.

Source: OECD. 
manufacturing industry reveals a particularly low import penetration rate for segmented industries with high R\&D intensities (Table 3). This may reflect the fact that this category includes many of Korea's leading industries, such as cars and communication equipment, where it has a strong comparative advantage. However, industries which have few domestic competitors and low imports, such as petrochemicals, oil refineries and cement, are more problematic from the perspective of competition.

Table 3. International comparison of import penetration by type of manufacturing industry ${ }^{1}$

\begin{tabular}{lcc|cc}
\hline & \multicolumn{2}{c|}{ High R\&D } & \multicolumn{2}{c}{ Low R\&D } \\
\cline { 2 - 5 } & Segmented & Fragmented & Segmented & Fragmented \\
\hline Austria & 51.9 & 42.6 & 27.9 & 29.5 \\
Belgium & 54.7 & 63.9 & 26.6 & 37.1 \\
Czech Republic & 43.3 & 41.3 & 25.8 & 25.7 \\
Denmark & 55.2 & 34.3 & 30.7 & 35.5 \\
Finland & 38.4 & 26.5 & 18.7 & 10.8 \\
France & 31.1 & 32.0 & 18.6 & 20.6 \\
Germany & 28.8 & 22.2 & 20.3 & 21.7 \\
Italy & 35.0 & 19.8 & 19.3 & 12.3 \\
Netherlands & - & 39.4 & 27.9 & 33.3 \\
Spain & 39.7 & 36.8 & 17.5 & 15.3 \\
Sweden & 34.9 & 30.0 & 25.2 & 17.8 \\
United Kingdom & 39.3 & 32.4 & 21.7 & 23.2 \\
United States & 26.4 & 22.7 & 10.2 & 14.4 \\
Canada & 44.2 & 55.9 & 21.0 & 22.9 \\
Japan & 8.0 & 7.2 & 8.4 & 8.7 \\
Korea & $\mathbf{2 0 . 0}$ & 38.5 & $\mathbf{1 4 . 4}$ & $\mathbf{1 3 . 7}$ \\
Mexico & 34.0 & 51.9 & 19.2 & 24.6 \\
European average & 39.9 & 34.1 & 22.3 & 22.9 \\
OECD average & 36.6 & 35.1 & 20.8 & 21.6 \\
\hline
\end{tabular}

1. Segmented market structures are characterised by large firms and significant entry barriers associated with high costs, while fragmented market structures are characterised by small firms and low sunk costs and entry barriers.

Source: See Oliveira Martins, J., T. Price and N. Mulder (2003) "A taxonomy of market structure cluster", OECD Economics Department, mimeo.

9. Explicit trade barriers in terms of tariff rates are higher than in other OECD countries due primarily to the protection granted to the agricultural sector. The average tariff rate in 2001 was 8 per cent, compared to around 3 per cent in the United States, the European Union and Japan (Table 4). However, the average rate for non-agricultural products in Korea was $4 \frac{1}{2}$ per cent, much closer to the rates in major OECD countries. The proportion of imports affected by non-tariff measures (defined as quantitative controls, finance measures and price control measures) is low at 2.4 per cent compared to more than 5 per cent in Korea's major trading partners (Panel B). However, imports are hindered by regulatory and administrative procedures in some areas, especially sanitation and safety, which are not consistent with international standards. For example, the Korean list of permitted food additives differs from the one agreed to within the FAO/WHO Expert Committee, and there are differences in cosmetic standards. 
ECO/WKP(2004)22

Table 4. International comparison of trade protection

A. Tariff rates in 2001 (per cent)

\begin{tabular}{lrrr|rrc}
\hline & \multicolumn{3}{c|}{ Simple average } & \multicolumn{3}{c}{ Weighted average $^{1}$} \\
\cline { 2 - 7 } & Total & Agriculture & Manufacturing & Total & Agriculture & Manufacturing \\
\cline { 2 - 7 } Korea & $\mathbf{1 2 . 7}$ & $\mathbf{4 4 . 2}$ & $\mathbf{7 . 3}$ & $\mathbf{7 . 9}$ & $\mathbf{6 4 . 1}$ & $\mathbf{4 . 5}$ \\
United States & 5.4 & 9.7 & 4.4 & 3.1 & 2.7 & 3.1 \\
European Union & 4.8 & 9.4 & 3.9 & 3.1 & 6.0 & 2.9 \\
Japan & 5.0 & 10.5 & 3.6 & 2.5 & 7.1 & 1.7 \\
\hline
\end{tabular}

\section{B. Coverage of non-tariff measures ${ }^{2}$}

\begin{tabular}{|c|c|c|c|c|}
\hline & Japan & Korea & United States & European Union \\
\hline Primary products & 7.49 & 9.29 & 4.69 & 1.98 \\
\hline Agricultural products & 7.69 & 10.76 & 4.56 & 2.30 \\
\hline Mining products & 6.31 & 0.60 & 5.44 & 0.47 \\
\hline Manufactures & 5.08 & 0.37 & 5.23 & 10.77 \\
\hline Iron and steel & 0.48 & 0.00 & 42.44 & 51.94 \\
\hline Chemicals & 1.15 & 1.25 & 3.35 & 4.18 \\
\hline Other semi-manufactures & 0.64 & 0.16 & 4.59 & 0.86 \\
\hline Machinery and transport equipment & 0.05 & 0.00 & 5.18 & 2.41 \\
\hline Textiles and clothing & 23.06 & 0.38 & 1.13 & 87.21 \\
\hline Other consumer goods & 0.68 & 0.00 & 0.92 & 4.82 \\
\hline Other products & 0.00 & 0.00 & 0.00 & 0.00 \\
\hline All products & 5.61 & 2.37 & 5.08 & 5.79 \\
\hline
\end{tabular}

1. Weighted by imports.

2. Coverage as a per cent of total imports in latest year available.

Source: World Trade Organisation for Panel A. UNCTAD for Panel B.

10. As noted above, the level of protection is much higher for agriculture. The overall level of support for farmers, as measured by the Producer Support Estimate, remains one of the highest in the OECD area and double the OECD average (Figure 2). The net effect is to boost farm income by nearly three times (Panel B). Over 90 per cent of this assistance is provided through market price supports, which distort trade and production, compared to an average of 66 per cent in the OECD area. For example, quotas remain in place for 190 agricultural products, and for 114 of these products, domestic producer cooperatives have exclusive rights to import or distribute import quantities within the quota limit, thus further limiting benefits from competition. The total support provided to farmers by Korean consumers and taxpayers amounted to $3 \frac{1}{2}$ per cent of GDP in 2003, according to the OECD. In addition to this direct cost, the high protection of agriculture is a major obstacle to the success of multilateral trade negotiations, as well as Korea's participation in regional free trade agreements, which would allow it to benefit more fully from the economic dynamism of Asia. ${ }^{6}$

6. The free trade agreement with Chile provoked severe opposition from farmers even though there is little agricultural trade between the two countries. This opposition delayed passage of the agreement by the National Assembly until February 2004 - 18 months after negotiations were completed. 
Figure 2. An international comparison of agricultural support
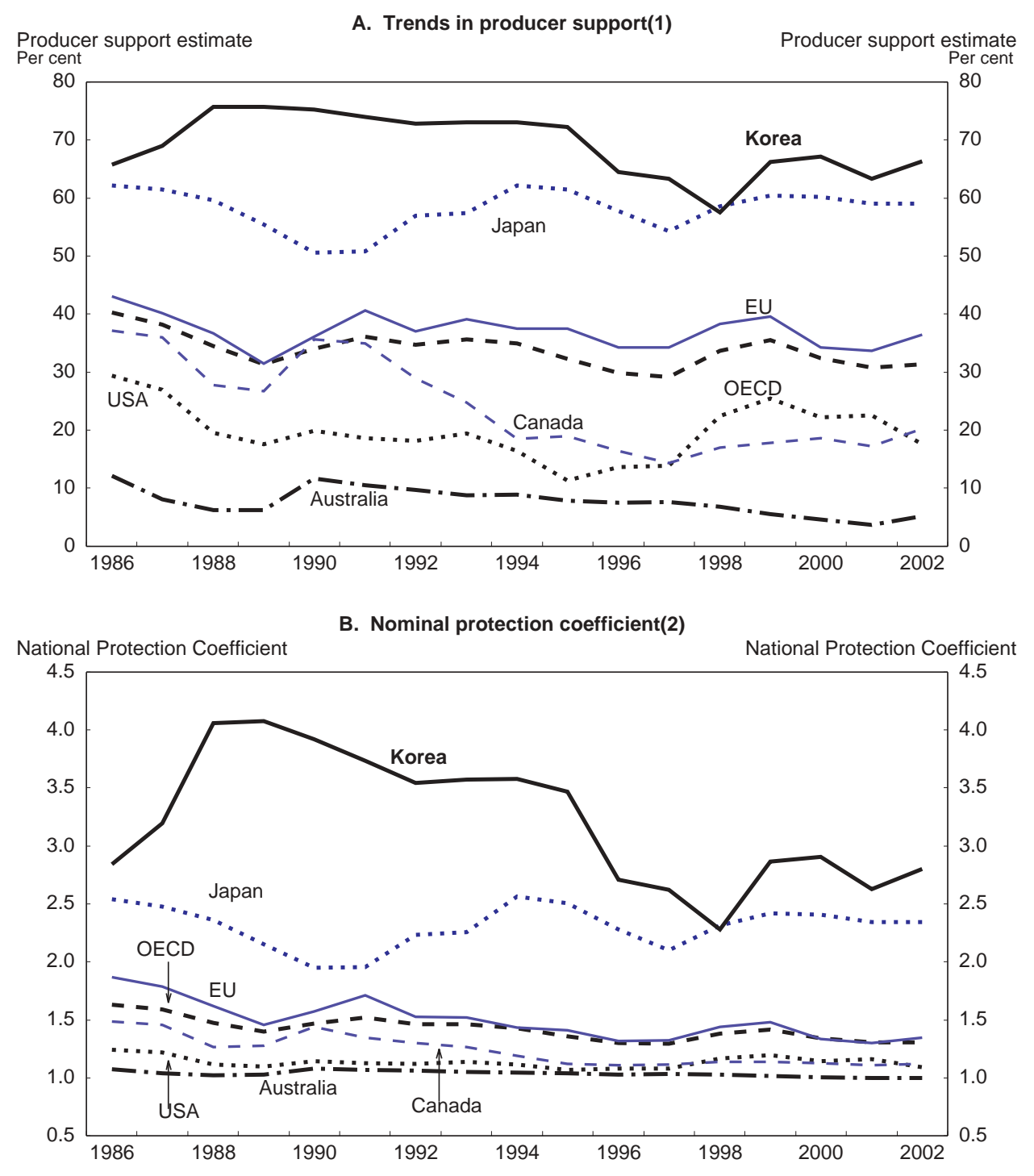

1. An indicator of the value of monetary transfers to agriculture resulting from agricultural policies. It is presented as a share of the total value of production at domestic producer prices.

2. The NPC is a measure of market protection defined as the ratio between the average prices received by producers and border prices.

Source: OECD, Agricultural Policies in OECD Countries.

11. Foreign direct investment (FDI) inflows had played a minor role in Korea prior to the crisis in 1997, reflecting a generally hostile attitude toward foreign investors and legal restrictions such as ownership and screening requirements, which were relatively restrictive compared to other OECD countries (Figure 3). However, the authorities have adopted sweeping measures to promote FDI, beginning with the Foreign Investment Promotion Act in 1998, which focused on creating an investor-friendly environment. At present, 99.8 per cent of all business lines (out of a total of more than 1 100) are open to 
foreign investment, a level on a par with that of other OECD economies. ${ }^{7}$ The amendment to the Foreigner's Land Acquisition Act in 1998 removed restrictions on foreign ownership of real estate. Perhaps even more importantly, the negative attitudes toward direct investment have been largely changed, as reflected in the creation of Invest Korea ${ }^{8}$ and the Office of the Investment Ombudsman to provide "one stop" service for potential investors and assistance after investment.

\section{Figure 3. Foreign direct investment restrictions, ${ }^{1} 1998$}

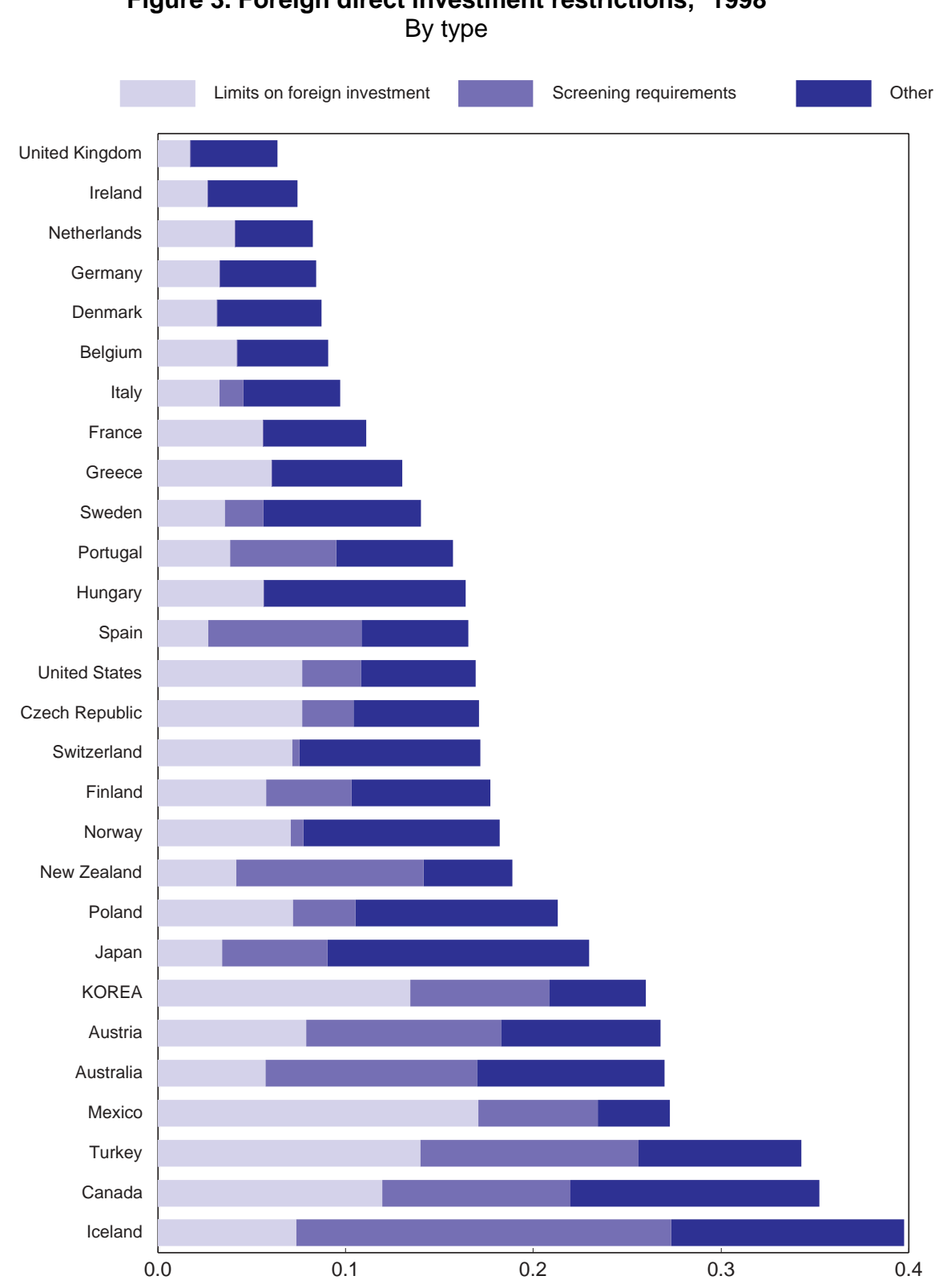

1. The indicator ranges from 0 (least restrictive) to 1 (most restrictive). Source: OECD.

7. Two business lines, radio and television broadcasting, are still closed to direct investment, while 27 are partially restricted. However, 78 firms are designated as defence-related companies in which foreign investment requires prior approval.

8. In 2003, the previous Korea Investment Centre was replaced by Invest Korea with newly adopted project manager (PM) system, which provides customised service to the foreign investors. 
12. The reforms to attract FDI and the restructuring of the corporate and financial sectors in the wake of the crisis, which caused a surge of cross-border M\&As, resulted in a sharp rise in FDI inflows (Figure 4). Indeed, the $\$ 35$ billion in actual inflows between 1998 and 2002 was more than double the amount received during the previous 35 years. This surge boosted the stock of FDI in Korea from 2 to 9 per cent of GDP. Nevertheless, Korea still ranks among the lowest of the OECD economies in this regard. Moreover, since 2001, the annual inflow of FDI has fallen below $\$ 5$ billion on an arrival basis, less than half of the amount in 1999 and 2000. The decline may be attributed to internal as well as external factors, such as the general slowdown in the world economy and in global FDI flows since 2001. Other

Figure 4. FDI inflows in Korea

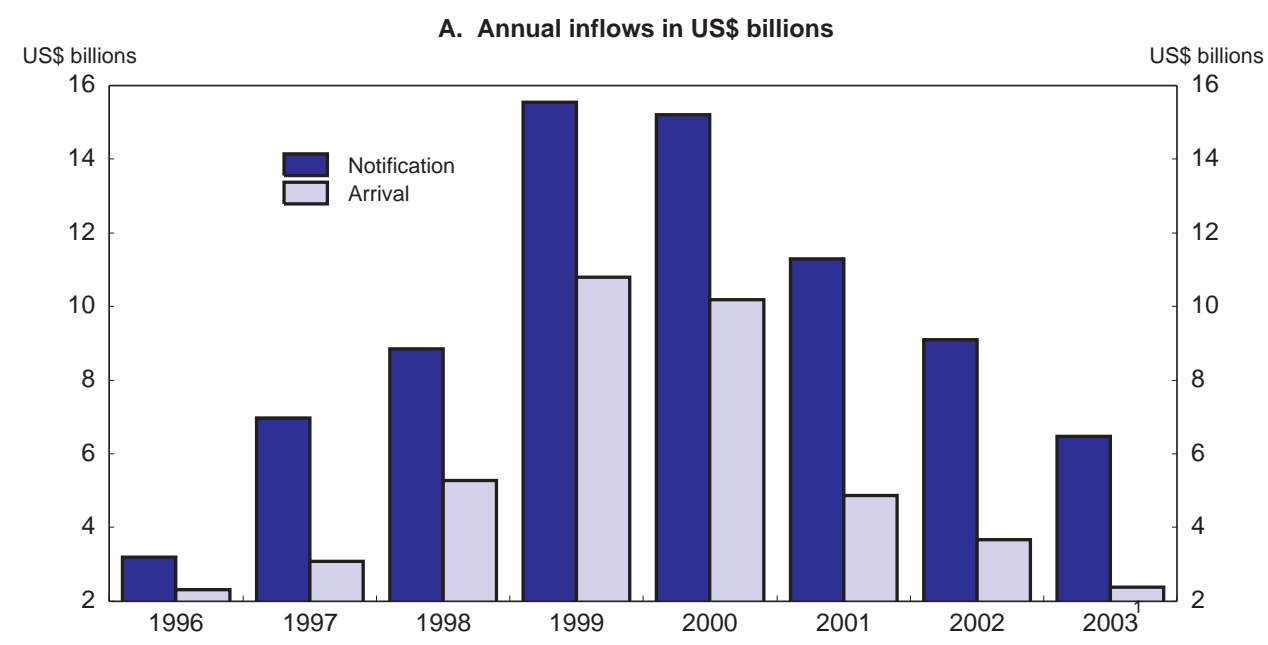

B. Stock as a share of GDP in $\mathbf{2 0 0 0}$

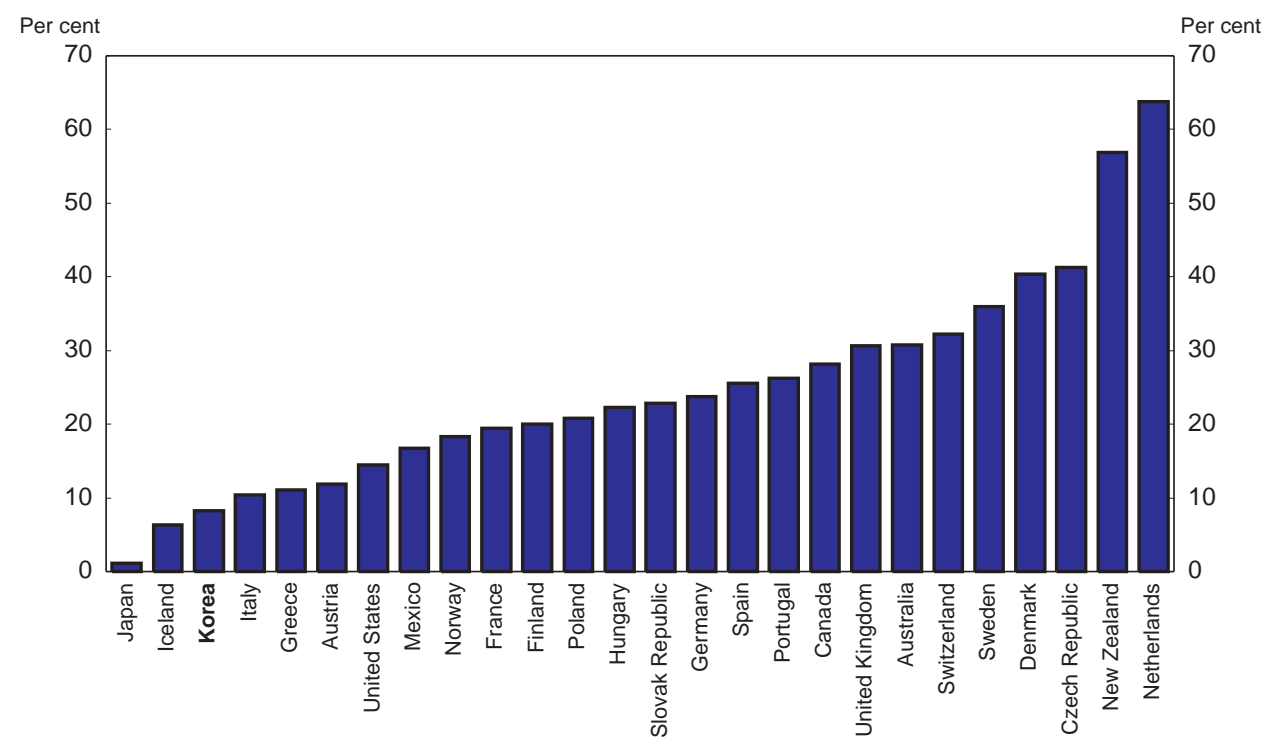

1. Amount arrived through September 2003.

Source: Ministry of Commerce, Industry and Energy for Panel A. OECD for Panel B. 
external factors include economic weakness in Japan, the largest foreign investor in Korea, the North Korean nuclear issue and the attractiveness of China as an investment site. The major internal factor has been labour problems, though it may also suggest that the liberalisation and promotional efforts by the Korean government have reached a threshold. The authorities have taken additional steps, notably by designating Incheon, Busan, and Gwangyang as "Free Economic Zones" (FEZs) in 2003. These zones, which offer a variety of advantages, are intended to make Korea an economic hub for Northeast Asia.

13. In summary, these indicators of concentration, import penetration and inflows of FDI suggest that competition has strengthened in recent years, particularly since the crisis. Nevertheless, the level of competition indicated by concentration and FDI inflows appears to be somewhat weak compared to other OECD countries.

\section{Enforcement of competition law}

14. The role of the competition enforcement body in Korea is unusually broad. Application of the 1990 Monopoly Regulation and Fair Trade Act (MRFTA) by the independent Korea Fair Trade Commission (KFTC) concentrates on horizontal constraints and unfair practices. The KFTC also applies laws to protect small businesses and consumer rights, and it is heavily involved in direct regulation of the structure, governance and operations of the chaebol. The KFTC systematically monitors industry structure in manufacturing, but most of the targets of its priority-setting "Clean Market Project" have been in services. In the last three years, these targets have included telecoms and broadband Internet service, medical services and pharmaceuticals, wedding and funeral services, construction materials, apartment and office rents, media, school uniforms, private instructional institutions, liquid natural gas, credit cards and insurance, Internet shopping, real estate agents and services, home maintenance services, job referral, electric power, instalment finance and banking, advertising, and professional certification. The sectors were chosen for monitoring by the competition authority because they have a direct and visible impact on consumers and because many have been significantly deregulated in recent years. The KFTC emphasises a law-enforcement approach along with its important advocacy and reform roles, and it is perceived as an aggressive prosecutor. Recent amendments to the law strengthen its enforcement tools.

15. In competition law enforcement, the KFTC pays most attention to horizontal collusion. The KFTC has tried to establish a per se rule against price fixing. The legal foundation for that approach, which treats such agreements as illegal in themselves without the need to show their effects in the particular case, is still uncertain in Korea. Nonetheless, the KFTC has scored several successes in price fixing and boycott cases. In two investigations in 2003, Korea's major cement firms and their trade association were fined 26 billion won ( $\$ 22$ million) and manufacturers of iron bar were fined 79 billion won ( $\$ 69$ million), and several of the parties were also referred for criminal prosecution.

\section{Enforcement and sanctions}

16. The basis for computing administrative fines, or "surcharges," was expanded in 1999. That change, combined with stepped up enforcement, greatly increased the sanctions actually imposed against competition violations. Fines against cartels in 2003 totalled 108 billion won ( $\$ 93$ million) and the total against competition violations over the period 1998 to 2003 -- about 455 billion won ( $\$ 393$ million) -greatly exceeds the 234 billion won over the previous decade. Yet provisions for financial sanctions are still less stringent than in most other Member countries. The ceiling on the administrative fine is 5 per cent of turnover related to the violation (or 1 billion won), and the level actually imposed is typically about 2.5 to 3.5 per cent. The KFTC has asked the National Assembly to double the ceiling for fines, which would make the multiplier comparable to that used in most of Europe (10 per cent). However, that level could still be effectively lower than it is in countries where sanctions are based on total firm turnover, not just the turnover related to the violation. Individual executives may also face criminal punishment in Korea. There 
have been a few prosecutions, but no one has actually gone to jail because sentences have typically been suspended. That may change, though. A trial court recently sentenced several defendants to up to a year in prison and the case is on appeal to the Supreme Court. Making the threat of individual sanctions credible will make it a more effective deterrent.

17. The KFTC has a leniency programme, which has produced enforcement results in about a half dozen cases. In addition to the prospect of a lower penalty, the KFTC programme offers a positive inducement to encourage individuals to come forward: a whistleblower may be awarded a substantial bounty of up to 100 million won $(\$ 86000)$. A reduction of criminal penalty may also be an incentive for participants in the corporate leniency programme. Nonetheless, the KFTC's investigative powers should be increased. Although stronger sanctions now apply to non-compliance with orders and investigations, information gathering powers remain designed for voluntary investigations. For example, the KFTC cannot search premises and take possession of evidence. Administrative law enforcement bodies that deal with labour, tariff, environment, and tax compliance have such powers, as does the prosecutor. To make the KFTC's administrative enforcement more effective and obviate the need to resort to criminal processes for inappropriate reasons, the KFTC needs such compulsory investigative powers. To supplement public enforcement, the right to bring a private lawsuit independently is being expanded. Private suits would no longer have to wait for the KFTC to decide first. The KFTC has also considered "public interest" suits to deal with damages to groups of individuals.

\section{Market dominance and merger policies}

18. In dealing with dominant firms and mergers, the KFTC focuses principally on structure, while showing increasing sensitivity to economic analysis of particular market situations. In characterising dominance, it uses three-firm concentration as its basic market structure test, while acknowledging that high concentration (by its measure, over 75 per cent) can be consistent with strong competition if the three large firms are all healthy. By defining dominance at a higher level of concentration than in many other OECD countries, the KFTC in effect permits more latitude to large-firm market conduct. The KFTC no longer maintains a listing of dominant firms subject to particular scrutiny. Claims about predatory low pricing are subjected to the sceptical "recoupment" test, that the predator be able to recover its losses by raising prices free from the challenge of competitive re-entry. The relatively permissive conception of dominance also means that merger control is more likely to permit large combinations. The structural test in the merger guidelines is slightly different, setting a basic threshold at a three-firm concentration of 75 per cent, but permitting some exceptions (based upon factors such as rank or relative market shares). Often large mergers may be efficient, especially if markets are international in scope. When the tests have been relaxed, such as when the KFTC approved restructuring transactions following the financial crisis (the socalled Big Deals), the KFTC has imposed behavioural restraints to deal with risks of market power. Recent merger decisions show reliance on structural as well as behavioural remedies. Modifications in the merger review system are planned, to expand the scope of required pre-notification and provide more time for investigation, while eliminating the notification requirement for small acquisitions. In 2003, rules were issued about the notification of foreign acquisitions with limited effect in Korea. These changes would bring Korea's system more closely into line with merger review systems in most other OECD countries. Some in the business community have unsuccessfully urged even more radical changes to the law, on the same grounds that they would bring Korea's law into line with the laws of other countries, namely eliminating its concern over aggregate concentration and its restrictions on the structure and conduct of the chaebol conglomerates. 
ECO/WKP(2004)22

\section{Policy toward the chaebol}

19. Regulating the chaebol is a significant KFTC function. The KFTC designates the firms that are subject to special regulation because of their size, enforces rules governing the structure of holding companies, limits total shareholdings outside a designated group and cross-holdings within it, limits loan guarantees within a group, restricts how financial affiliates in a group can vote shares, and polices "undue" transactions within a group. The KFTC considers these functions to be as important as competition law enforcement, and the KFTC is just as stern in enforcing these rules, periodically announcing enforcement campaigns to check for undue transactions and other violations. Since 1998, nearly half of the financial sanctions imposed (341 billion won out of a total of 752 billion won) were against violations of the chaebol rules. The KFTC refined its approach in 2002, in part because reforms since 1997 have changed chaebol structure and conduct. Rather than list the top 30 groups in total assets and apply uniform controls to all of them, the KFTC now differentiates them according to their total assets. In the 2003 designation, there are 17 "type A" chaebol that are subject to a ceiling on total shareholding of other domestic companies (a limit that can be lifted if the group corrects its excessive debt-equity ratio), and 49 "type B" chaebol that are subject to controls on cross-shareholdings and debt guarantees; all of the "type A" groups are also "type B." The KFTC plans to ask the National Assembly to delete provisions about the debt-equity ratio, which exempt some chaebol from the ceiling on shareholding, and to extend the KFTC's powers to demand financial information from financial institutions concerning their customers' "undue" transactions.

20. The investigation of "undue" intra-group transactions is the chaebol regulation that is most closely related to conventional conceptions of competition law. Subsidies in the form of transactions within a group on more favourable terms are conceived to present competition problems analogous to state aid subsidies. For example, the KFTC contends that if a firm should be liquidated according to market standards, but an affiliated firm props it up, the result is anti-competitive because entrenching inefficient large firms bars entry of potentially more competitive small ones. The analogy to anti-competitive state aid was more apt when it appeared that the chaebol, or some of them, would be treated as too big to fail. In the absence of implied government support for the supposed subsidies, there should be a stronger presumption that transactions will be subject to the discipline of market forces, even within a group - although controlling shareholders may nonetheless try to escape that discipline. KFTC monitoring in the absence of any such implicit guarantee is reminiscent of older styles of regulatory intervention, such as control over firms' investment decisions and adherence to consensus price levels. Suspicious intra-group transactions may involve unfairness or something like predation, but more often the real problem is misappropriation, breach of fiduciary duty, or embezzlement. KFTC enforcement actions against clearly identifiable threats to market competition are of course necessary, but actions may fail where they aim at corporate misconduct that is not actually anticompetitive. Meanwhile, the new laws and institutions for dealing with corporate misconduct could remain underdeveloped as long as the KFTC is occupying the field.

21. The KFTC contends that the other aspects of its unusual enforcement agenda are consistent with reliance on markets for growth and efficiency, because transparent structures and fair competition support confidence in market transactions, thus encouraging the flow of resources into productive uses. That general "dynamic efficiency" motivation is undermined by some of the rules' constraining effects. For example, concerns have been expressed that the ceiling on chaebol shareholdings may make it more difficult to set up large-scale projects that require teaming substantial Korean firms as strategic investors with substantial foreign investors; however, the KFTC has not found any instances of projects that could not be done for this reason. The KFTC also defends its continued attention to corporate governance and investment matters on the grounds that corporate, financial, and securities laws and regulatory institutions are not yet established well enough to do the job adequately. Meanwhile, it is relaxing the requirements for forming holding companies, a structure that would increase transparency. Although holding companies were first allowed in 1998, the conditions attached have meant that only a handful have been created thus far. In addition, the KFTC has proposed a "Three-Year Market Reform Roadmap" that would offer chaebol 
incentives to improve their corporate governance practices and ownership structure. This proposal, which is under consideration by the National Assembly, would set specific criteria that would allow companies to graduate from the regulations on equity investment. At the same time, the KFTC intends to provide more information on corporate governance and ownership structure to investors and stakeholders.

22. Opaque corporate structures needed to be cleared up, because they allowed financial leverage at a scale that undermined stability. To do that task, the KFTC was more independent and effective than the existing financial regulators, although they failed to prevent the problems that led to the 1997 crisis. But there have been numerous reforms to improve corporate governance, financial soundness, and transparency since 1997. Other enforcement agencies, notably the Financial Supervisory Commission and the Financial Supervisory Service, which were created in 1998, are in place to deal with problems related to corporate financing. Supervisory functions related to internal cross-holdings and guarantees and intra-group transactions that amount to misuse of corporate assets should be concentrated in regulators responsible for financial and securities matters. Transactions that have an exclusionary or distorting effect on product market competition in particular cases should still be subject to competition-law control.

\section{Exemptions from the competition law}

23. The scope of exemptions from competition law is now limited. Government entities are subject to the same rules as private enterprises. Equal treatment applies to chaebol regulation too, as large government entities are now designated as groups whose transactions are regulated, and the KFTC has fined several of them for undue transactions and abuse in relationships with contractors. Claims that anticompetitive conduct is authorised by official action are treated sceptically. The KFTC has intervened against several cartels whose members claimed they had acted pursuant to administrative guidance. But some sectors are still protected or controlled to some extent. Notably, liner shipping conferences are exempted by special legislation on the grounds that they are "internationally recognised" cartels. Many exemptions were eliminated by the Omnibus Cartel Repeal Act of 1999, which eliminated statutory authority for 17 cartels, thus prohibiting fee-setting arrangements for a number of professional services. However, some of the changes were delayed (see below).

24. Several programmes to favour small and medium-sized enterprises (SMEs) appear to distort competition. The most significant of these -- preventing entry by larger firms in as many as 88 business lines -- is to end in 2004. The most pervasive programme, permitting wide-ranging cooperatives, is subject to a competition test, but these groups should be watched carefully, as their self-regulatory codes of unfair practices could impair competition. The government planned to cut back a system of small-business "cartels" in government procurement, reducing them to 154 items in 2000 and intending to cut further to 103, but the National Assembly rejected the second stage. This system does not prevent buyers from seeking sources other than the cartel, and permitting a degree of co-ordination among very small firms could be efficient. But efficient collaboration should not need legislative exemption from competition law.

\section{Unfair competition and consumer protection roles}

25. The KFTC protects small business interests directly, through rules about unfair practices, particularly in dealing with suppliers and subcontractors. And it protects consumers directly too, through rules about unfair marketing practices and misrepresentation. These functions can complement competition enforcement, although some "fair trade" rules that limit promotional offers could risk dampening market competition. In other cases, the KFTC is concerned that rules imposed by others to protect consumers may limit competition. For example, in dealing with the credit card problems, which some saw as the result of excessive competition for customers, the FSC wanted companies to control premium offers because they threatened financial stability. At the same time, the KFTC was concerned about the anti-competitive 
effects of self-regulation. On the grounds that changing rules and eligibility without notice was unfair to consumers, the KFTC ordered the card issuers to make clearer disclosures of the terms of their offers.

\section{Regulatory policies at the sectoral level}

26. Korea's government-driven growth policy has included regulations on over-investment that resulted in various entry barriers, such as licensing, permission, nomination, government monopoly and reporting requirements. According to a government study, 63 per cent of all industries -- 205 out of 325 -had regulations controlling market entry (KDI, 1997). A private-sector study in 2002, which used more detailed industry categorisation, found that 36 per cent of all industries were subject to entry barriers (Table 5). The non-manufacturing sector is subject to more barriers, and those barriers are stronger compared with the manufacturing sector. Entry barriers in specific sectors, such as retail trade, professional services, and network industries, will be discussed below. As for the exit mechanism, it appears to have been improved. In particular, the disappearance of about half of the top thirty chaebol in 1997 has demonstrated that no firm is "too big to fail". However, the widespread use of workout or private restructuring programmes, rather than the revised bankruptcy procedures, reflects weaknesses in the Composition Act and the Company Reorganisation Act. This may tend to delay liquidation and third-party takeovers.

Table 5. Entry barriers in Korea

Number of industries

\begin{tabular}{|c|c|c|c|c|c|}
\hline & $\begin{array}{c}\text { Total } \\
\text { industries }\end{array}$ & $\begin{array}{c}\text { Strong } \\
\text { barriers }\end{array}$ & $\begin{array}{c}\text { Weak } \\
\text { barriers }\end{array}$ & $\begin{array}{c}\text { Total } \\
\text { industries } \\
\text { with barriers }\end{array}$ & $\begin{array}{l}\text { Per cent of } \\
\text { all industries }\end{array}$ \\
\hline \multicolumn{6}{|l|}{1992} \\
\hline Manufacturing & 585 & 103 & 85 & 188 & 32.1 \\
\hline Non-manufacturing & 610 & 249 & 104 & 353 & 57.9 \\
\hline Total & 1195 & 352 & 189 & 541 & 45.3 \\
\hline \multicolumn{6}{|l|}{2001} \\
\hline Manufacturing & 585 & 42 & 73 & 115 & 19.7 \\
\hline Non-manufacturing & 610 & 147 & 165 & 312 & 51.1 \\
\hline Total & 1195 & 189 & 238 & 427 & 35.7 \\
\hline
\end{tabular}

Source: Jaehong Kim (2002).

27. Regulatory policies in service sectors vary widely in scope. Although retail distribution and professional services are inherently competitive sectors, entry controls and self-regulation hamper competition. Strengthening competition requires applying the competition law forcefully in these sectors. On the other hand, network industries have segments with "natural monopoly" where competition is difficult -- or even impossible -- to introduce. In such areas, regulators should ensure non-discriminatory access to networks for third parties and open potentially competitive segments to competition. International experience has shown that the gains from regulatory reform in network industries are potentially very large if reforms are carefully designed. 


\section{ECO/WKP(2004)22}

\section{The use of land}

28. One factor having an important impact on competition is land-use regulation. The extensive controls on land use, combined with government policies that limit the available supply and drive up its price, can act as entry barriers. The concern about land use reflects its relative scarcity; Korea has the third highest population density in the world (excluding city-states) at 487 inhabitants per square kilometre. Moreover, two-thirds of the country is mountainous and nearly half of the population is concentrated in the capital region.

29. The use of land is directed by 315 zoning regulations, established by 112 different laws, which are administered by 13 different ministries (see Jung, 2003). As a result, 5.7 zoning regulations are applied on average to each parcel of land, and sometimes many more. In some cases, zoning regulations contradict each other, and co-ordination between ministries is difficult. A new framework for policy co-ordination requiring that any changes in zoning be discussed with the Ministry of Construction and Transportation was introduced in 2003. While this is a positive step towards a more coherent land policy, the new law covers only 69 of the zoning regulations. Transparency is further reduced by the limited database on land, which provides information on only 33 zoning regulations, thus making it very difficult for a landowner to be aware of the restrictions imposed on a specific plot.

30. Another problem is the limited amount of land available for development in the face of growing urbanisation. Although the share of the urban population reached 88 per cent in 2000, only 5.8 per cent of total land is allocated for urban development, compared to 13 per cent in the United Kingdom and 7 per cent in Japan. The government has tended to favour preservation over development through extensive restrictions on land use, resulting in high prices. Developing land or transferring it to other uses is an extremely difficult and time-consuming process, thus frustrating the efficient use of land.

31. The land-use problem is also related to the intensity of concentration in the capital region, which includes the cities of Seoul and Incheon and Kyonggi Province. The region, which only has 12 per cent of the national territory, contains 47 per cent of the total population. The related annual social costs are estimated to be 10 trillion won for congestion and 4 trillion won for environmental effects, amounting to 2 per cent of GDP. Despite policies during the past twenty years to limit the growth of the capital region, concentration has continued to increase, while leaving remote regions relatively under-developed. ${ }^{9}$ The continued growth of the capital region indicates that congestion costs have been outweighed by the benefits of locating in the region. Among these benefits, proximity to the nexus of business activities and availability of better educational facilities seem to be important to firms and households. In 2003, the government announced a plan to move the administrative capital from Seoul to Chung Cheong Province, which is located in the middle of the country (Box 1). ${ }^{10}$ The Special Act on Construction of the New Administrative Capital was enacted in December 2003, and the site for the new administrative capital will be determined by the end of 2004. The actual relocation will start from 2012, after a five-year construction period.

9. In the capital region, development activities have been highly regulated by the Act on Consolidation Planning for the Capital Region and the Consolidation Plan. Construction of large facilities is restricted by imposing quotas on manufacturing industries and universities, or by levying "congestion charges" on business buildings and government facilities. The development of large sites for residences, factories and sightseeing requires approval from the government. Meanwhile, tax measures are aimed at discouraging concentration and encouraging firms to move away from the capital region.

10. In the mid-1990s, units of ten central government agencies moved to Daejeon, the largest city in Chung Cheong Province. 


\section{Box 1. Building a new administrative capital city}

The relocation schedule is composed of four stages; preparation in 2003, planning between 2004 and 2007, construction between 2007 and 2011, and actual relocation beginning in 2012. The new administrative capital will be an independent city located at some distance from major towns. The optimal size of the city is suggested to be around $76 \mathrm{~km}^{2}$, with the population to increase in line with its development. The first phase is to be finished by 2020 with a projected population of 300 thousand. It should rise to $1 / 2$ million by the end of the second phase in 2030 . Most central government institutions will be relocated to the new capital. However, it has not been decided whether to move the legislative and judicial branches.

The estimated cost of constructing the new capital city is 45.6 trillion won (6 per cent of GDP) through 2030. The public sector will bear 11.3 trillion won of that amount for constructing government buildings and highways, while the private sector will cover the remaining 34.3 trillion won for other facilities such as housing and city infrastructure. The budgetary burden would be reduced by utilising the proceeds from the sale of existing government buildings in the capital region and encouraging private participation in infrastructure projects.

The projected impact on the population is a decrease of 513 thousand people in the capital region by 2030, with an increase of 651 thousand people in Chung Cheong Province. The net annual saving in congestion costs is estimated to be 1.2 trillion won. In addition, there is expected to be downward pressure on real estate prices in the capital region (1.5 per cent for land and 1.0 per cent for housing). Some immeasurable benefits are also expected, such as more balanced territorial development and a reduction in regional disparities.

\section{Retail distribution}

32. Korea's retail industry has been evolving, driven by more efficient formats such as large discount stores, whose market share rose to 10 per cent in 2000 from only 1 per cent five years before. The growing foreign presence, which started in 1996, is also an important factor in driving structural change. ${ }^{11}$ However, compared to other OECD countries, the sector is still dominated by small, family-run establishments (Table 6). Labour productivity in Korea's retail industry is reported to be around 30 per cent of that in the United States, making it the lowest among OECD economies. ${ }^{12}$ Regulations aimed at protecting small mom-and-pop stores and promoting investment in manufacturing industries have long impeded the development of the retail industry and have contributed to the low productivity in this sector. Indirect regulations, such as zoning, and a cumbersome application process to open large-scale stores have also had a significant effect on the retail market (Figure 5). Indeed, regulations on the establishment of retail outlets have been judged to be the most restrictive in the OECD area. ${ }^{13}$

11. Three (Carrefour, Wal-Mart, and Costco) of the top twenty retailers are now foreign-owned, and a partnership between Samsung and Tesco was formed in 2002.

12. McKinsey (1998) estimated Korea's labour productivity in the retail industry at 32 per cent of the US, and 59 per cent of Japan. Meanwhile, a recent analysis estimated labour productivity in the distribution industry to be 29 per cent of the United States and 34 per cent of Japan and France on the basis of PPP (see Suh et al., 2002).

13. This result differs from another study (OECD, 2000c), which ranked Korea as one of the countries with less stringent regulation. This study considered general restrictions on access, regulations on operations, and price regulations, but did not take account of other regulations governing the location of sales outlets, such as zoning and promotional activities. 
Table 6. Key structural features of the retail distribution sector 2000

\begin{tabular}{|c|c|c|c|c|}
\hline & \multirow{2}{*}{$\begin{array}{l}\text { Outlet } \\
\text { density }^{1}\end{array}$} & \multirow{2}{*}{$\begin{array}{l}\text { Employees } \\
\text { per } \\
\text { enterprise }\end{array}$} & \multirow{2}{*}{$\begin{array}{l}\text { Wholesale and retail } \\
\text { distribution, total } \\
\text { value added per } \\
\text { employed person }\end{array}$} & \multirow{2}{*}{$\begin{array}{c}\begin{array}{c}\text { Non-specialised } \\
\text { stores }^{2}\end{array} \\
\begin{array}{c}\text { Share of total output } \\
\text { in retail distribution } \\
\text { (per cent) }\end{array}\end{array}$} \\
\hline & & & & \\
\hline Austria & 43 & 7.7 & 90 & 20 \\
\hline Belgium & 80 & 3.5 & 114 & 35 \\
\hline Denmark & 47 & 8.1 & 79 & 39 \\
\hline Finland & 46 & 5.0 & 82 & 44 \\
\hline France & 64 & 4.2 & 87 & 37 \\
\hline Germany & 35 & 9.0 & 75 & 23 \\
\hline Italy & 130 & 2.2 & 101 & 31 \\
\hline Netherlands & 54 & 8.5 & 81 & \\
\hline Portugal & 150 & 2.5 & 66 & 31 \\
\hline Spain & 133 & 2.8 & 71 & 32 \\
\hline Sweden & 65 & 4.3 & 79 & 34 \\
\hline United Kingdom & 36 & 14.2 & 68 & 43 \\
\hline European Union & 71 & 6.3 & 83 & 35 \\
\hline Japan & 111 & 5.7 & 74 & $16^{3}$ \\
\hline Korea $^{4}$ & 132 & 2.3 & & 25 \\
\hline
\end{tabular}

1. Number of outlets per 10000 inhabitants.

2. Includes large-format outlets such as hypermarkets and department stores.

3. Share of large stores only.

4. As of 2001.

Source: Eurostat, New Cronos, Japan Statistics, National Statistical Office in Korea.

33. Special regulations -- over and above general urban planning rules -- apply to retail outlets in most OECD countries, thus posing a risk to market entry and competition. Moreover, the influence of established retailers on local authorities may make entry particularly difficult for outsider companies (OECD, 2001b). In Korea, retail outlets of more than $1000 \mathrm{~m}^{2}$ are prohibited in residential and industrial areas (Table 7). While there are no regulations on building large-scale stores in commercial zones, such zones account for only 0.2 per cent of the nation-wide land area. Moreover, most of this area is already occupied by other businesses, making available locations too small for large-scale stores. Re-development requires long and complex negotiations to get agreement from multiple owners. Since 1996, the construction of discount stores of up to $10000 \mathrm{~m}^{2}$ in area has been allowed in the "natural green areas" located in urban districts. However, regulations, such as limits on building- and volume-to-land ratios, have hindered the construction of large-scale retail outlets in these zones. ${ }^{14}$

14. Ceilings of 20 per cent for the building-to-land ratio and 100 per cent for the volume-to-land ratio are applied in the natural green area, thus making large shopping malls unprofitable (see Suh et al., 2002). 
34. The cumbersome process to receive permission to open a new large-scale store has been an important barrier in the retail sector. Agreement from the local government is required in the process of transport impact evaluation and construction approval. As in some other OECD countries, the devolution of authority to local governments may be problematic for achieving greater competition in the retail sector since local authorities tend to be even more susceptible than national governments to pressure by incumbent firms and other vested interests. In some cases, local authorities levy additional burdens, such as quasi-taxes. ${ }^{15}$ However, there are no regulations on operational issues such as shop opening hours and price controls.

Figure 5. Regulatory indicators in the retail industry ${ }^{1}$

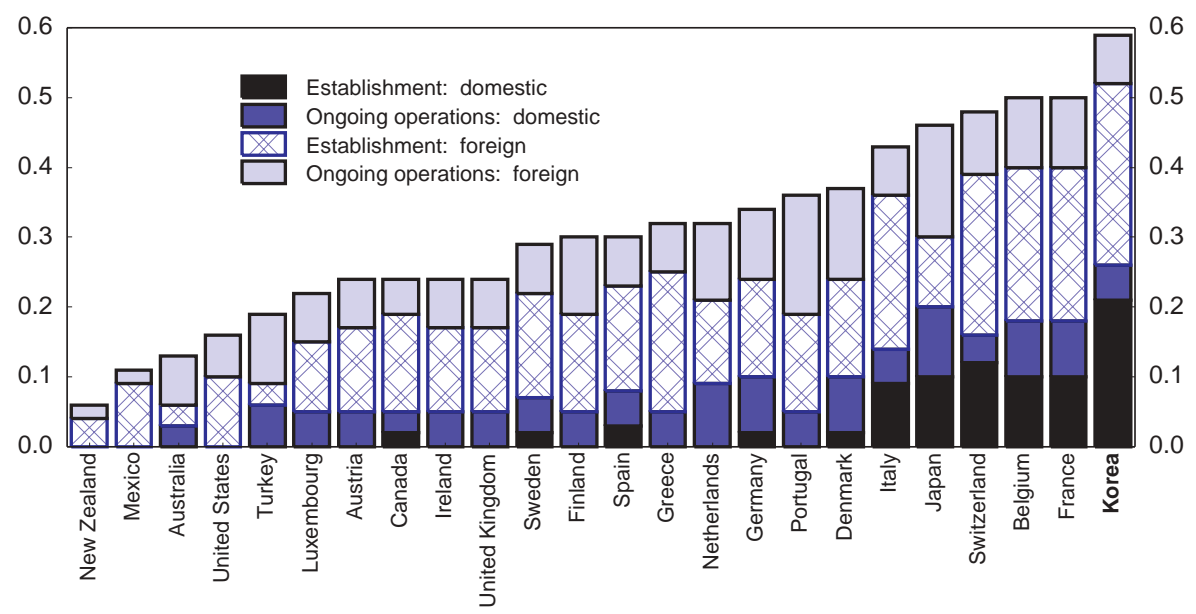

1. The restrictive index scores range from 0 to 1 . The higher the score, the greater the restrictions.

Source: Kalirajan (2000).

35. In 1996, Korea eliminated most of the restrictions on the size and number of retail stores that a foreigner could open. Since then, there have been further liberalisation steps such as abolishing remaining restrictions on retailing by foreigners in department stores and shopping centres. Meanwhile, an economic needs test applies to retail outlets for used cars and gas fuels. However, the barriers noted above, such as zoning regulations and the complicated and time-consuming application process, are probably more cumbersome to foreign investors, given their lack of knowledge concerning the local regulatory environment. ${ }^{16}$

15. There have been seven administrative litigation cases concerning unreasonable rejection of proposals for large-scale stores. Moreover, additional costs, such as quasi-taxes and coerced contributions, are normally 7 to 8 per cent of total construction costs (Dong-Whan Kim, 2003). In 2002, MOCIE issued a ministerial order asking local governments to avoid levying too heavy a burden on new large-scale entrants for such expenses as land and construction costs to build entrance roads.

16. Complaints from foreign retailers to the Office of the Investment Ombudsman indicate that they have serious concerns about the transparency of government administration and lack confidence in it (Kim and Choo, 2002). 


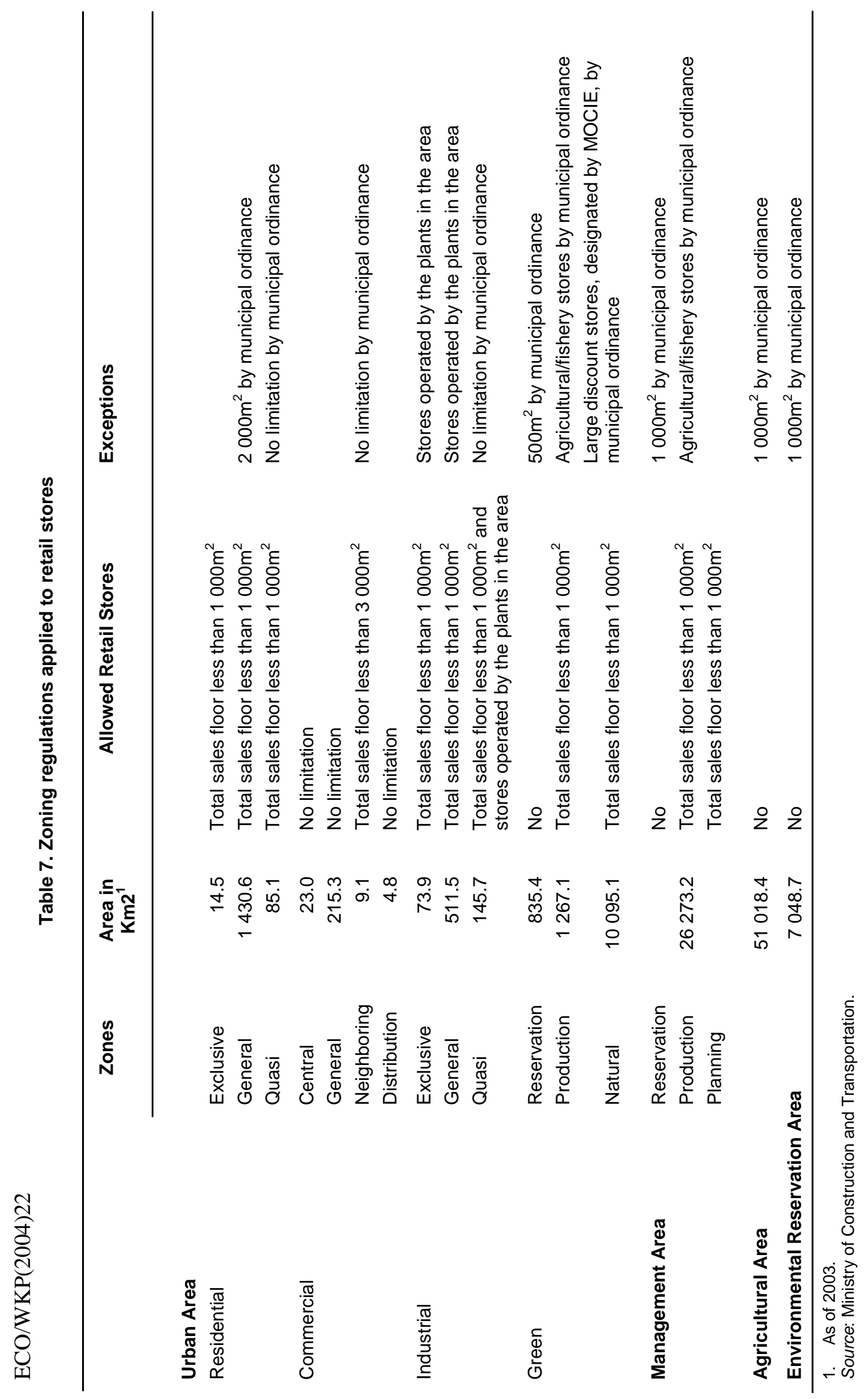




\section{Professional services}

36. All OECD countries regulate the activities of professional services, either directly or by delegating regulatory powers to professional associations, as a means to protect consumers by alleviating information asymmetries and ensuring high-quality services. In Korea, regulations in accounting are highly restrictive compared to other OECD countries, while those in the legal, architectural and engineering services are relatively moderate (Figure 6). These regulations typically govern matters such as entry into the profession, the conduct of members of the profession, the granting of exclusive rights to carry out certain activities, and the organisational structure of professional firms. However, such regulation can have the direct or indirect effect of restricting competition, raising prices and limiting variety and innovation in professional services.

Figure 6. Regulations of professions: restrictiveness indices for OECD countries
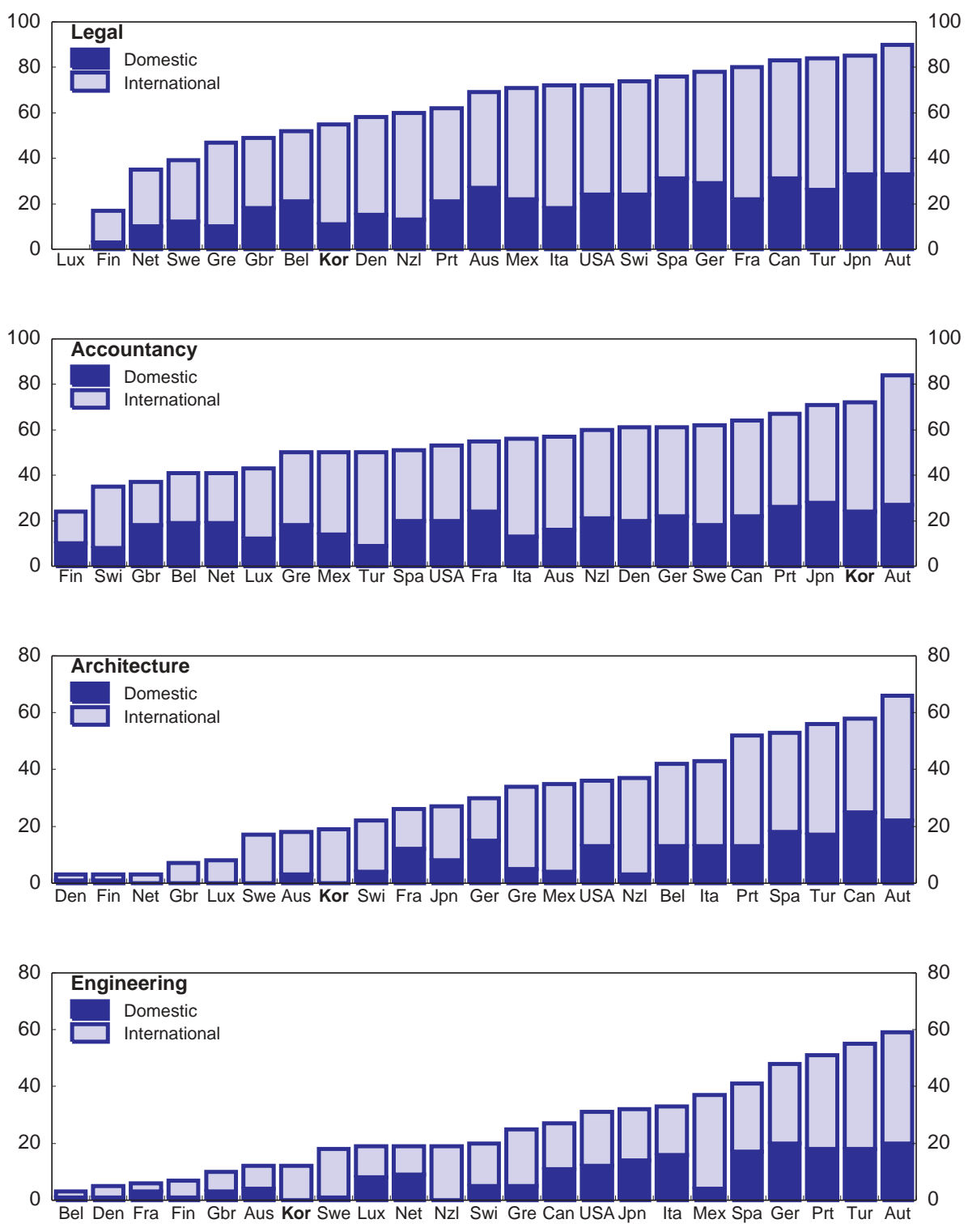

Source: Nguyen-Hong (2000). 


\section{Deregulation of professional services}

37. In 1998, the Regulatory Reform Committee (RRC) launched a reform programme covering 155 trade associations that were performing regulatory functions based on legislation. ${ }^{17}$ For example, the law had established 48 trade associations, giving them a monopoly in their fields and requiring all professionals to join. The RRC's reform programme examined such compulsory requirements, the delegation of powers (e.g. registration and discipline), training requirements, and regulations concerning establishment and operation. As a result, the compulsory establishment and membership in 36 trade associations was abolished, allowing more than one association to be established, and giving professionals the choice of whether to join the associations (Table 8). However, the target of the reform plan was not fully achieved since some of the planned changes for professional associations, including lawyers and certified public accountants (CPAs), were modified or discarded in the National Assembly, thus allowing those associations to maintain their regulatory schemes.

Table 8. Deregulation of professional associations Number of associations

Planned reform

Abolish compulsory establishment and membership

Withdraw delegated power for registration

Withdraw delegated power for discipline

Abolish mandatory training

Abolish authority for performance evaluation

Abolish authority for certification of foreign trade

Reform exam management

Reform other delegated authority

Deregulate requirements for entry

Deregulate requirements in operation

\begin{tabular}{rrc} 
Target & Implemented & $\begin{array}{c}\text { Modified } \\
\text { or discarded }\end{array}$ \\
\hline 48 & 36 & 12 \\
5 & 2 & 3 \\
5 & 3 & 2 \\
70 & 54 & 16 \\
6 & 6 & 0 \\
19 & 19 & 0 \\
13 & 9 & 4 \\
31 & 29 & 2 \\
82 & 68 & 14 \\
112 & 97 & 15
\end{tabular}

Source: Regulatory Reform Committee.

38. In 1999, the Omnibus Cartel Repeal Act (OCRA) was enacted to abolish or reduce the scope for concerted activities that had been granted exemption from the Monopoly Regulation and Fair Trade Act by sectoral legislation. For example, fees in nine professional services -- lawyers, CPAs, architects, certified tax accountants, patent attorneys, customs brokers, certified labour services, administrative recorders and veterinarians -- had been set by professional associations and approved by the relevant ministries. The OCRA made restrictions on fee-setting illegal and addressed a number of other non-competitive practices. ${ }^{18}$ Following the enactment of the OCRA, the KFTC has closely monitored information on prices

17. This was part of the extensive deregulation accomplished following the 1997 crisis. The RRC, established in 1998, led to the elimination of 48.9 per cent of the 11095 existing regulations, while 42.5 per cent of the remaining regulations were reformed (see the 2000 OECD Economic Survey of Korea).

18. The provision allowing premium-fixing by insurance companies was revised, the number of products in which SMEs are allowed to conduct group negotiations for contracts was reduced, co-ordination directives by the government were limited to cases in which they are required to comply with inter-governmental agreements or in the export of military equipment, government co-ordination of bidding competition for 
to respond to potential problems that could result from the introduction of price competition. A survey by the KFTC reported a significant decline in the fees in the affected sectors (see the 2001 OECD Economic Survey of Korea). In 2003, five professional services (lawyers, CPAs, architects, certified tax accountants, and judicial recorders) were included in the Clean Market Project for close scrutiny.

39. Despite significant progress, the pace of change in some professions remains relatively slow and incremental, in part because of the large economic rents at stake and the intense interest of professional associations. The restriction on fee-setting for architects was reintroduced in 2001, although it took the form of direct notification by the government rather than delegating the power to the professional association. In addition, regulations, rather than market competition, set fees for notaries and engineers. The KFTC is planning a second OCRA to eliminate remaining overly-generous exemptions.

\section{Lowering entry barriers}

40. Entry barriers, such as quantitative limits on entry and unnecessarily high entrance requirements, may hinder competition and allow economic rents in the professional services. ${ }^{19}$ The RRC launched a programme to lower entry barriers in seven professional services (CPAs, certified tax accountants, patent attorneys, customs brokers, property appraisers, certified labour services, and administrative recorders). ${ }^{20}$ This was accomplished by raising the ceiling on the number of persons admitted annually (and eventually abolishing quantitative limits), reducing the qualifications for taking selection exams, and limiting the advantages given to government officials. ${ }^{21}$ Committees to monitor selection policies were established in the relevant ministries, and professional associations are no longer allowed to exercise exclusive control over entrance standards and exams. The reforms to lower entry barriers resulted in at least a doubling in annual entry between 1997 and 2002 in such professions as CPAs, certified tax accountants, patent attorneys, custom brokers and judicial recorders (Table 9). Lower entry barriers in these areas are expected to provide better and more diverse services. Entry into accounting is constrained, though not prevented, by the requirement of membership in the professional association and the rule that only a CPA can establish an accounting corporation.

41. Of the remaining exemptions and regulatory constraints on competition, those involving the legal profession may be the most important. Limits on the admission of new lawyers and unnecessary restraints on forms of practice undermine the development of stronger legal oversight of corporate governance and hamper foreign investment. Foreign lawyers have requested permission to set up branch offices, form joint ventures with Korean law firms, and employ Korean and foreign lawyers (see Office of Ministry for Trade, 2003). However, foreign licenses are not recognised in Korea, and foreign lawyers can only be employed

overseas construction projects was eliminated, and territorial allocation in the supply of unsterilised rice wine was abolished.

19. The RRC stated, "According to the National Tax Service's material submitted to the National Assembly in 1998, the average annual revenues of patent attorneys, lawyers, and certified tax accountants were 400, 250, and 190 million won, respectively" (Maeil Business Newspaper, 21 October 1998). The average annual wage for all workers was 17 million won in 1997.

20. As for lawyers and judicial recorders, reform was implemented by the professions and the related ministry.

21. In some professional services, government officials with long experience (generally at least ten years) in related fields had been exempt from examinations. According to the RRC, the ratio of retired government officials in 1998 was 100 per cent for administrative recorders, 94.2 per cent for judicial recorders, 85.6 per cent for customs brokers, 62.1 per cent for certified labour services, 29.0 per cent for patent attorneys, and 24.5 per cent for certified tax accountants. Limiting the advantages given to government officials will provide more open and fair competition for entry. 
as "legal assistants" in local firms. ${ }^{22}$ Limitations regarding commercial presence and the recognition of qualifications of other countries restrict the availability of international professional services, such as legal and accounting services. Since these are factors that encourage foreign investors, failure to open the market can act as an indirect barrier to FDI. The WTO's service negotiations provide an opportunity to further reinforce competition in the professional services market.

Table 9. Number of entrants per year in the selected professional services ${ }^{1}$

\begin{tabular}{|c|c|c|c|c|c|c|c|c|}
\hline & $\begin{array}{c}1997 \\
\text { (A) }\end{array}$ & 1998 & 1999 & 2000 & 2001 & 2002 & $\begin{array}{c}2003 \\
\text { (B) }\end{array}$ & B/A \\
\hline Lawyers & 604 & 700 & 709 & 801 & 991 & 998 & 905 & 1.5 \\
\hline CPAs & 453 & 511 & 505 & 555 & 1014 & 1006 & 1003 & 2.2 \\
\hline Certified tax accountants & 306 & 301 & 354 & 451 & 603 & 699 & 717 & 2.3 \\
\hline Patent attorneys & 71 & 80 & 81 & 121 & 200 & 202 & 204 & 2.9 \\
\hline Customs brokers & 18 & 62 & 60 & 74 & 94 & 77 & 140 & 7.8 \\
\hline Property appraisers & 101 & 100 & 100 & 135 & 183 & 117 & 135 & 1.3 \\
\hline Judicial recorders & 0 & 30 & 52 & 80 & 101 & 100 & 60 & $2.0^{2}$ \\
\hline Certified labour services & 43 & 37 & n.a. & n.a. & n.a. & n.a. & 61 & 1.4 \\
\hline Administrative recorders ${ }^{3}$ & 0 & 0 & 0 & 0 & 0 & 0 & 0 & - \\
\hline
\end{tabular}

1. Covers only those who passed regular entrance exams (excludes those allowed to enter due to experience in the field).

2. Compared with 1998.

3. The examination for selection will be introduced in 2005

Source: Ministry of Justice, Ministry of Finance and Economy, National Tax Service, Korean Intellectual Property Office, Korea Customs Service, Ministry of Construction and Transportation, Supreme Court of Korea, Ministry of Labour, Regulatory Reform Committee.

\section{Network industries}

42. The liberalisation of network industries in a number of OECD countries during the past decade has generally resulted in substantial price reductions. However, there are examples of less successful reforms or outright failures, although these are mostly related to design problems of deregulation rather than liberalisation per se. This section will discuss the electricity, gas and telecommunication sectors in Korea. In electricity and gas, ambitious long-term restructuring programmes have become stalled and these sectors remain dominated by state-owned monopolies. The most progress has been made in telecommunications, though the dominance of the leading companies in some markets raises concern.

\section{The regulatory scheme}

43. Multiple regulators are involved in the network industries, which are subject to the competition laws and regulations enforced by the KFTC. The competition law does not apply to practices that are allowed by other laws, although the Monopoly Regulation and Fair Trade Act states that a ministry must consult with the KFTC when enacting a law that could have anti-competitive implications. In practice, the KFTC and relevant ministries have shared responsibility, with the former accountable for competition issues and the latter for technology and economic issues. This raises concern about consistency in implementing regulations. In some areas, including mergers, business transfers, and access to essential facilities, the relevant ministry and the KFTC are required to consult in order to avoid potential conflicts.

22. Korea's "Initial Offer submitted to the WTO in March 2003" is somewhat limited. Foreign lawyers without domestic licenses will be allowed to supply "advisory services" on the law in the jurisdiction where they are qualified as lawyers and on public international law. Moreover, commercial presence in the form of a representative office will be required and lawyers have to stay in Korea at least 180 days a year. 
44. Along with its regulatory function, each ministry has broad powers to promote the development of the relevant industry, in contrast to regulatory bodies in other OECD countries that are charged with protecting consumer interests and promoting competition. ${ }^{23}$ Given that fair and transparent regulatory supervision requires that the regulator distance itself from interested parties, there is a large risk of conflict between ministries' industry promotion role and their regulatory functions. Sector-specific regulators, such as the Korea Communication Commission (KCC) and the Korea Electricity Commission (KOREC), were established in response to privatisation and deregulation in the network industries. ${ }^{24}$ Although they have the potential to become independent regulatory bodies, they operate within the ministries, and lack autonomy regarding both crucial regulations, such as licensing and pricing, and their own staffing and budgeting.

45. Tariffs of network industries are basically based on rate of return (ROR) regulation, which is not sufficient to provide an incentive to reduce costs and improve efficiency. ${ }^{25}$ Information asymmetries between regulator and business hamper the scheme to find optimal prices, and deregulation in the network industry will raise costs of implementing ROR regulation. The industry promotion role of the regulator may also bring about distortions in tariff structure as shown, for example, in the electricity sector. A more transparent pricing scheme such as a price cap may be an alternative. The implementation of a price cap would prevent non-sector specific considerations from distorting the process of building competition and improving efficiency, and would ensure a smooth and rapid adjustment to a cost-reflective pricing structure.

\section{The electricity sector}

46. The Korea Electric Power Corporation (KEPCO), which is the largest business group in Korea, completely dominates the electricity market. It is the only licensed corporation in transmission and distribution and its six generating subsidiaries produce 96.7 per cent of all electricity generated. ${ }^{26}$ Although 45 per cent of KEPCO's shares are held by private investors, government influence over tariffs is strong. Tariffs, which have to be approved by the Ministry of Commerce, Industry and Energy (MOCIE), have been held down by regulating the return on equity, which fell from 11.5 per cent in 1980 to around 5 per cent in 2001 and 2002. The government retains the right to appoint all board members and the chief executive. Entry to and exit from the electricity business is controlled by MOCIE through a licensing process. ${ }^{27}$ Given that there are no interconnections with other countries, there is no possibility of foreign competitive pressures. As for the price of electricity, Korea is among the lower group in OECD countries when measured at current exchange rates (Figure 7).

23. For example, the Telecommunications Basic Act provides MIC with the power to "advise" facility-based carriers on where to invest, a provision that is used to justify the mandatory contributions imposed on carriers to contribute to $R \& D$.

24. A law submitted to the National Assembly in 2001 would establish an Energy Commission that would absorb KOREC and regulate both the electricity and gas sectors. However, the law is still pending due to the delays in reforms in the gas sector. Creating such a combined regulator responsible for both sectors may have some advantages, such as limiting the scope for regulatory capture (see OECD, 2004).

25. A study, which recommended adopting price caps and introducing an independent regulator, pointed out the lack of incentives as the most serious problem of ROR regulation. In contrast, over-investment has not been problematic in Korea (Nam et al., 2001).

26. Although each is completely owned by KEPCO, they are run as legally separate companies. In addition, there are 19 independent power producers, which account for 3.3 per cent of total electricity production.

27. However, small power plants with generating capacity of less than $3000 \mathrm{~kW}$ are licensed by local governments, with advice from KOREC. 

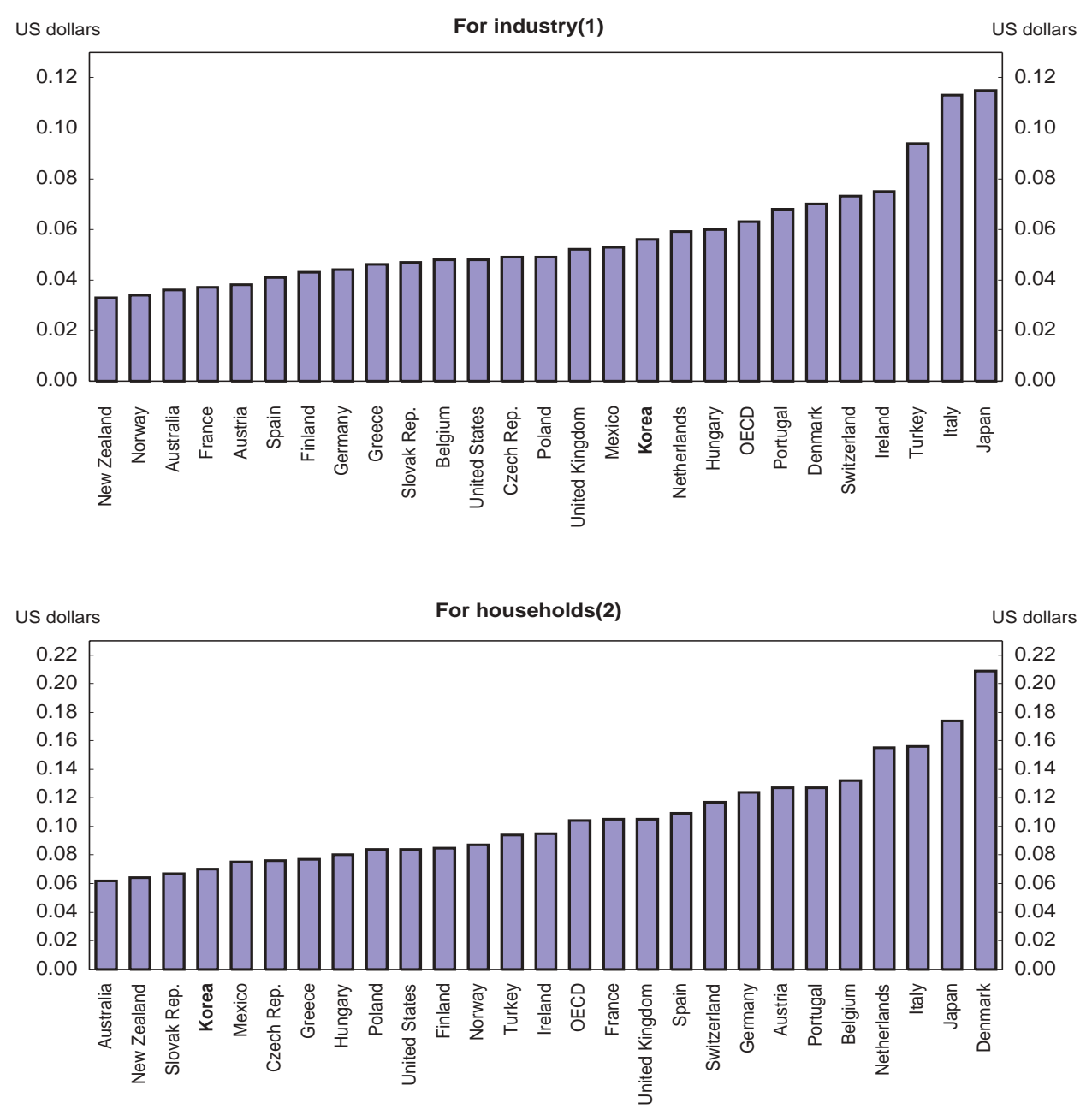

1. Price excluding tax for Australia and the United States. Data is for 2000 for Austria, Belgium and total OECD.

2. Prices excluding tax for the United States. Data is for 2000 for Belgium and total OECD. Source: OECD.

47. In 1999, the government released the Basic Plan for Restructuring the Electricity Industry, which aimed at introducing competition in four phases (Table 10). According to the plan, the generating capacity and distribution facilities would be separated from KEPCO and privatised, leaving KEPCO as the only transmission company in Korea. The ten-year reform plan has been advancing, though it is somewhat behind the original timetable. Competition was introduced to power generation in 2001 with the spinning off of KEPCO's power-generating capacity into six subsidiaries and the establishment of the Korea Power Exchange (KPX) as a cost-based trading pool. Large consumers (those with capacity of over $50000 \mathrm{kVA}$ ) were allowed to buy electricity from the KPX directly in 2003. Of the six subsidiaries, five thermal powergenerating companies are to be privatised, while the sixth, the Korea Hydro and Nuclear Power Co., will remain a subsidiary of KEPCO due to security reasons. ${ }^{28} \mathrm{~A}$ regulated third-party access system for

28. As of 2002, the generating capacity and actual generation of the Korea Hydro and Nuclear Power Co. were 36.4 and 40.6 per cent, respectively, of those of KEPCO's six subsidiaries combined. Therefore, it is 
transmission, which is consistent with practices in the majority of OECD countries, was put in place to facilitate electricity trade between generators and large customers. The terms and conditions of access are required to be non-discriminatory by law, and rate of return regulation is applied to determine the transmission fee level. However, the first attempt to privatise one of the generating subsidiaries through an international bidding process failed in 2003, and the government is now considering gradual privatisation through initial public offerings. The design of a two-way bidding pool has been completed, and mock cyber-operations have been conducted since July 2003.

Table 10. The original plan for reforming the electricity sector

Phase 1:

Status mid-1999

Phase 2:

Power Generation

Competition (2000-2002)

Phase 3/Phase 4: Wholesale Competition (2003-2008)/ Retail Competition (2009-)
- KEPCO is a vertically-integrated utility (generation, transmission, distribution) with 5.5 per cent of power purchased from independent power producers.

- KEPCO's power generation capacity is separated into six competing subsidiaries that are to be privatised in stages

- Distribution subsidiaries created to distribute power to captive customers

- A cost-based pool electricity market established

- An Electricity Commission created within MOCIE

- $\quad$ KEPCO becomes principally a transmission and nuclear power business

- Distribution subsidiaries are privatised

- Open access to power transmission grids

- Bid-based generator pool electricity market commences in Phase 3

- Independent brokers of electricity will be permitted in Phase 3

- Consumers select power providers in Phase 4

- Electricity Supervisory Board established

Source: Ministry of Commerce, Industry and Energy.

48. There are some weaknesses in the plan. First, the timetable for liberalisation for consumers, which is very vague, appears to offer choice to most consumers only a decade after the reforms began. Second, there is considerable uncertainty about the plan's details, which reduces confidence. For example, the extent of privatisation and the method of achieving it are uncertain, and it was announced that the privatisation of the distribution subsidiaries would be reconsidered later, which has a direct impact on the value of the generating companies that are supposed to be privatised. However, probably the most significant obstacle to reform is the lack of consensus between the parties concerned, including consumers and labour unions. By early 2003, the reform process had lost its momentum and the subsequent timetable had become unclear. In September 2003, the government set up a Tripartite Joint Study Group to consider how to split the distribution function; the government is awaiting the report from this Group before announcing its position.

expected that the generation market will remain more concentrated than in some other OECD countries. It draws attention to the risk and advantages of having a single publicly-owned company holding nuclear plants and giving it a mandate to construct new base load plants. This could distort competition (see IEA, 2002a). 
49. There are two other potential obstacles to creating competition in the electricity market that are related to pricing. One is that the tariff structure is characterised by significant distortions between sectors that offer the scope for cross subsidisation (Figure 8). According to MOCIE estimates, industry paid 80 per cent of the average sales price of electricity and farmers paid only 57 per cent, while households and commercial customers paid substantially more than the average. However, the difference in prices between sectors has been reduced gradually. ${ }^{29}$ Meanwhile, consumers pay higher costs because of "quasigovernmental" functions. In 2001, the Electric Power Industry Fund was established to take responsibility for some of these functions. Although the new approach is more transparent, electricity consumers bear the final burden since the Fund is financed through a surcharge on electricity bills. ${ }^{30}$

Figure 8. Electricity charges by sector, 2002

As a per cent of average sales price ${ }^{1}$

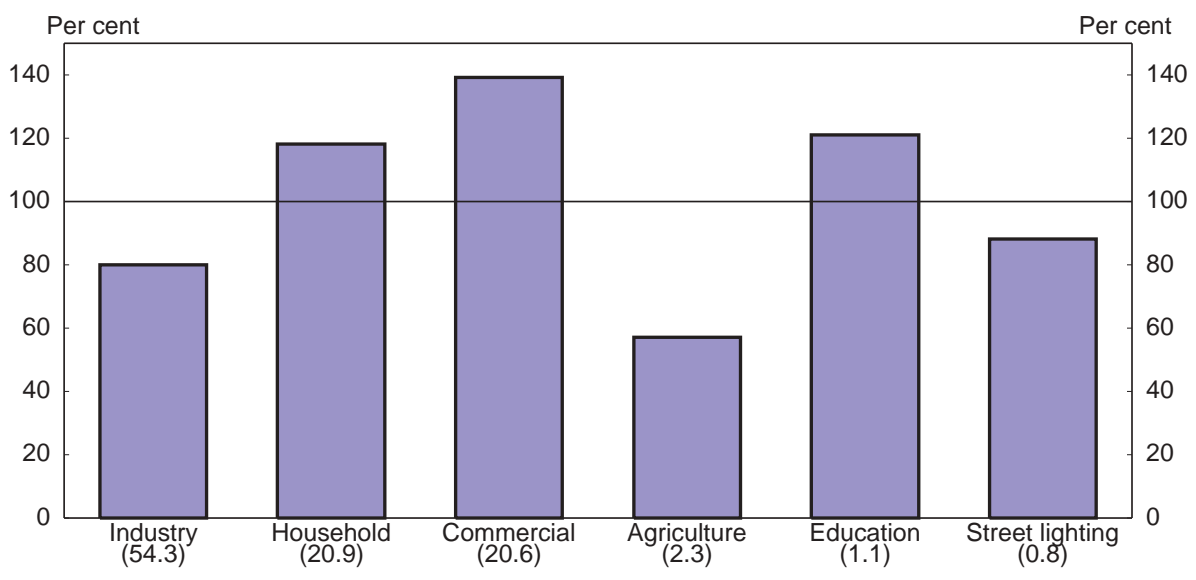

1. The numbers in parentheses show the share of total sales in each sector. Source: Ministry of Commerce, Industry and Energy.

\section{The natural gas sector}

50. Currently, there is no competition in any area of the Korean gas industry. The Korea Gas Corporation (KOGAS), the state-owned monopoly, manages the import, storage, transmission, and wholesale distribution of natural gas, which exceeded 18 million tons in 2002. Korea has no indigenous production of natural gas, and thus depends entirely on liquefied natural gas (LNG) imports. ${ }^{31}$ Besides performing the role of facility operator, KOGAS also supplies natural gas for retail city gas companies and for power generation, which is provided directly without passing through a retail distribution network. ${ }^{32}$ As

29. In 2003, prices for industrial use were raised by 3 per cent, while prices for household and commercial uses were lowered by 2 per cent. In 2004, prices for household, commercial and educational uses were further lowered by 3 per cent.

30. The Fund is financed by an earmarked charge of 4.6 per cent of the electricity bill. The Fund is expected to spend 1.2 trillion won (about \$1 billion) in 2003.

31. Korea is the second largest importer of LNG next to Japan, and KOGAS is the world's largest LNG importing company. There is no import of pipeline natural gas (PNG). However, the possibility and viability of PNG imports from eastern Siberia are currently being explored.

32. The gas industry relies heavily on the electricity industry as a swing consumer to flatten out seasonal fluctuations in demand, which is due to heating. In 2002, KOGAS supplied 7 million tons of LNG (36.8 per cent of total consumption) to ten power-generating companies, including five subsidiaries of KEPCO. 
for the local distribution and retail market, there are 32 private city gas companies, all but four of which purchase natural gas from KOGAS and supply it to end users through their own distribution pipelines. ${ }^{33}$ Competition in those markets is impossible, since the city gas companies are granted territorial monopolies and have no obligation to allow access to their distribution pipelines.

51. In 1999, the government announced the Natural Gas Industry Restructuring Plan, which aims at restructuring the industry to introduce competition, and then privatising KOGAS (see IEA, 2002b). The government's share has been reduced to 61 per cent. The reform underway in the electricity industry also necessitates changes in the gas industry, because KEPCO is both the largest customer and major owner of KOGAS. According to the plan, KOGAS will spin off its gas import and wholesale units into three affiliated companies, while keeping the facility sector a state-owned company using an Open Access System. The retail supply businesses will be separated into facility operation and gas sales, as in the wholesale sector, in order to spur competition, which will require interconnection among rival pipelines.

52. However, implementation of the plan has been delayed. KOGAS has not yet been split, and the three restructuring-related laws, which were submitted to the National Assembly in 2001, have not been approved. $^{34}$ The main problems lie in the characteristics of LNG imports ${ }^{35}$ and the challenge of restructuring KOGAS (see IEA, 2002b). ${ }^{36}$ In 2003, the government decided to revise the original plan. As for the import and wholesale sectors, the decision will be made after thorough debates on how to spin-off the three subsidiaries and whether to allow new entry. Even if new entry is permitted, it is likely to be subject to certain restrictions, at least in the early stage of competition, due to the inflexibility of existing long-term import contracts.

53. Wholesale natural gas tariffs are subject to approval by MOCIE, while the supply terms and conditions, including the retail gas tariffs, of city gas companies require approval from the local government. ${ }^{37}$ The basic approach used in deriving supply costs is rate of return regulation, while "yardstick regulation" is used for some city gas companies. Where several city gas companies exist in a city or province, a single retail price is applied to all the companies. Thus, a company that has relatively high costs cannot fully recover them under the allowed rate of return.

33. The remaining four companies use liquefied petroleum gas (LPG) as feedstock.

34. The three new laws include the revision of the KOGAS Law and the City Gas Business Law and the enactment of the Energy Commission Law to establish a sector regulator.

35. LNG import contracts have long terms of 20 to 25 years, and commit buyers and sellers to strictly defined obligations, including take-or-pay clauses that require the buyer to pay for a certain amount of gas whether taken or not, as well as an obligation on the part of the seller to make available defined volumes of gas. Such contracts provide a firm basis for both buyers and sellers to finance a highly capital intensive infrastructure. Project financing is normally used for the construction of LNG carriers. Conditions in case of a default on loans that are imposed on the charter agreement for the carrier require a certain level of government ownership, including local governments. In the case of KOGAS, it ranges from 30 to 51 per cent.

36. First, splitting KOGAS's import contracts among three affiliated companies is extremely difficult, because suppliers will not agree to have their contracts reassigned without solid guarantees. Second, KOGAS will no longer be the world's largest, most powerful LNG importer, and the three new importing companies may find themselves bidding against each other, resulting in higher import prices. Third, privatising KOGAS is not consistent with the default provisions for LNG vessels. Fourth, the scope for competition is limited by the unchangeable conditions of existing long-term import contracts.

37. The gas tariff consists of feedstock cost and supply costs such as re-gasification, storage, and transmission. The feedstock cost changes automatically bimonthly (monthly for power generation customers) according to fluctuations in oil prices and exchange rates, while the supply costs are approved on an annual basis. 
54. There is some cross-subsidisation for policy purposes. KOGAS gives financial incentives for gasoperated cooling systems in the hope of smoothing seasonal fluctuations in demand by promoting gas sales during the summer season. Tariffs for public welfare facilities and compressed natural gas for buses are also discounted in an effort to reduce air pollution. ${ }^{38}$ The government is planning to finance such obligations on a transparent basis as the restructuring proceeds. However, there is no obligation for retail companies to provide services to any customers below cost.

\section{The telecommunication sector}

55. Korea's telecommunication sector has been advancing at a remarkable pace, thanks to the rapid spread of high-tech services and the introduction of competition in this sector. ${ }^{39}$ Telecommunication prices for both residential and business-sector users are among the lowest in the OECD area (Figure 9). As for broadband, penetration is the highest in the world, while charges are low compared to other OECD countries. However, Korea's telecommunication industry is struggling to handle a series of destabilising developments, and concerns over Korea Telecom (KT) and SK Telecom's market dominance are growing (Table 11). Some competitors are faced with financial difficulties. In 2003, Hanaro was taken over by a foreign consortium, and Onse Telecom and Thrunet Co. were forced to seek protection from creditors.

56. Market entry was liberalised during the 1990s and there is no longer an a priori limit on the number of market entrants in any of the designated license categories. The current license classification system requires authorisation for facility-based providers, registration for special service providers and notification for VAN providers. ${ }^{40}$ Licenses for fixed facility-based services are differentiated by the type of service offered (local, long distance or international). A prospective licensee thus needs to apply for multiple licenses. Moreover, requests for licenses for facility-based services are accepted only two weeks during the year. However, entry barriers were lowered by abolishing the up-front contribution fee for new fixed-line providers in 2002, while the mandatory annual contribution from service providers for R\&D was also lowered from 3 per cent of sales to 0.5 per cent.

57. Interconnection charges are a difficult issue in Korea, as in other OECD countries. The "essential facilities doctrine", which was introduced to the Monopoly Regulation and Fair Trade Act in 2001, makes the failure to allow access to essential facilities an abuse of dominant position. Interconnection arrangements between operators with no market power are regarded as commercial matters to be decided by agreements between them, which must be notified to the Ministry of Information and Communication (MIC). In contrast, interconnection agreements involving operators with "significant market power", i.e. KT and SK Telecom, are subject to authorisation by the MIC. In the case of fixed interconnection charges,

38. In 2001, the amount of support for air conditioning use was 42 billion won, while support for the last two were 1.1 and 0.3 billion won, respectively.

39. The formerly monopolistic market, dominated by KT in fixed-line telephony service and SK Telecom in mobile service, shifted to a more competitive structure during the 1990s. For local service, Hanaro entered in 1999, while Dacom and Onse entered the long distance and international markets during the 1990s. For mobile service, Shinsegi entered in 1994, followed by three Personal Communication Service (PCS) operators in 1996. For International Mobile Telecommunication (IMT-2000) service, SK IMT and KTicom were selected as asynchronous (W-CDMA) providers in 2000. In 2003, SK IMT was merged into SKT, while KTicom was merged into KT. For balanced development of synchronous and asynchronous transmission, LG Telecom was approved as a synchronous CDMA provider in 2001. Asynchronous (WCDMA) service started in the Seoul area in 2003, while synchronous service will be provided by 2006.

40. Facility-based services cover wire telephony, cellular telephony, PCS, TRS, CT-2, radio paging, and leased line services, while special services cover Internet telephony, international call-back, premises communications, and voice resale. Value-added services provide PC online, Internet, E-mail, and voice mail services. 
KT's charge is applied as a "standard" for other operators. Mobile interconnection charges have been set asymmetrically for cellular and PCS operators, taking into account the different nature of frequencies and other cost factors. ${ }^{41}$

Figure 9. Telecommunication charges in the OECD

US dollars, November 2003
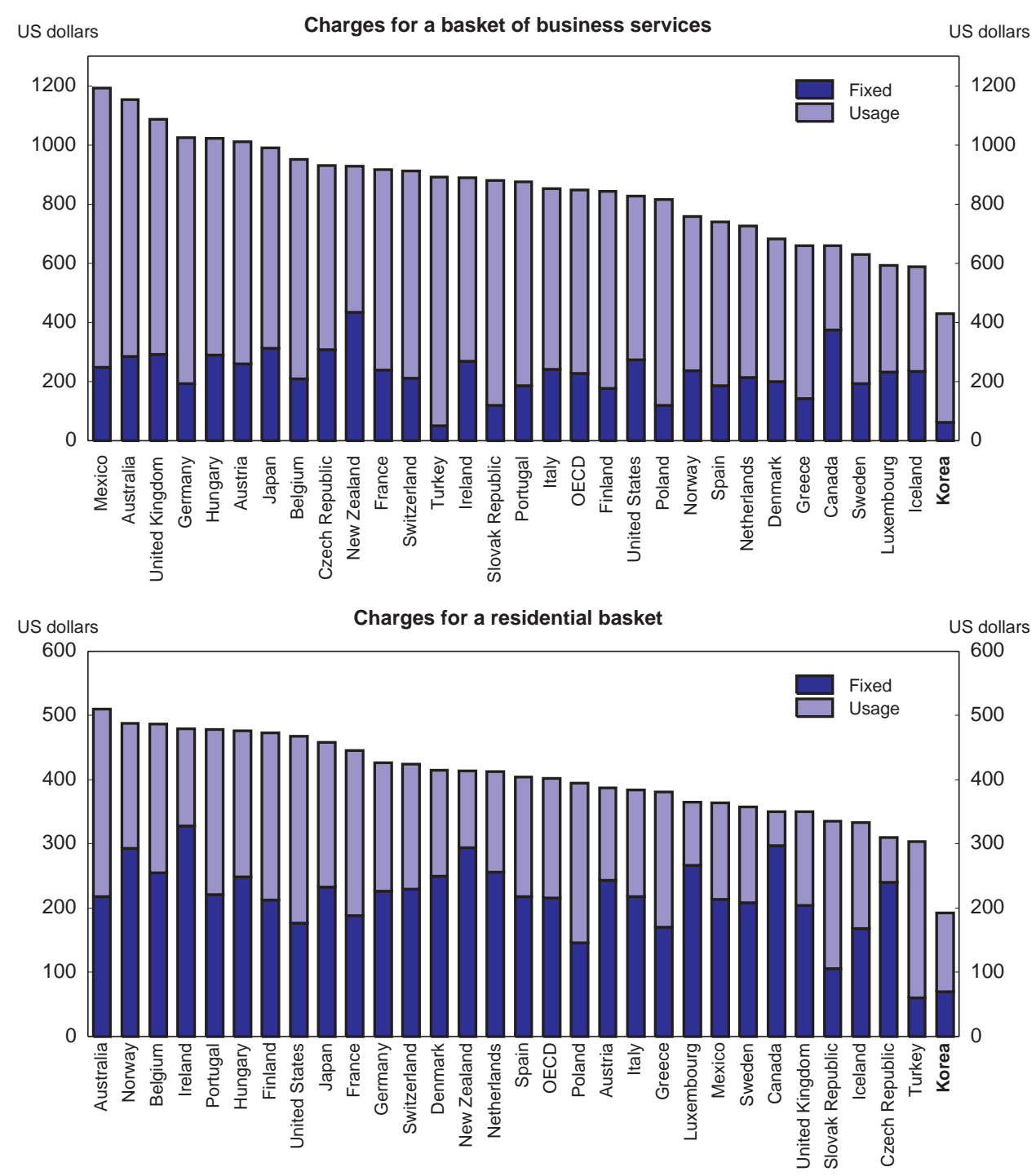

Note: Composite basket includes international calls and calls to mobile networks. Source: OECD and Teligen.

41. For land to mobile (LM) calls, SK Telecom, KT Freetel, and LG Telecom receive 41.0, 48.0, 52.9 won per minute respectively. SK Telecom, which is a cellular service provider, is providing better quality services due to the characteristics of its frequency. PCS providers insist that SK Telecom is able to cut costs by 40 to 50 per cent using low frequency $800 \mathrm{MHz}$, while PCS providers use $1.8 \mathrm{GHz}$. 
Table 11. Competition in the telecommunication sector 2003

\begin{tabular}{|c|c|c|c|}
\hline & $\begin{array}{c}\text { Market size } \\
\text { (trillion } \\
\text { won) }\end{array}$ & $\begin{array}{c}\text { Number of } \\
\text { major } \\
\text { operators }\end{array}$ & Market share \\
\hline Local telephone & 5.6 & 2 & KT 95.6\%, Hanaro Telecom 4.4\% \\
\hline Domestic long distance & 1.3 & 4 & $\begin{array}{l}\text { KT } 76.7 \% \text {, Dacom 19.5\%, Onse Telecom 3.8\%, Hanaro } \\
\text { Telecom } 0.0 \%\end{array}$ \\
\hline International telephone & 1.1 & 4 & $\begin{array}{l}\text { KT } 39.5 \% \text {, Dacom } 18.0 \% \text {, Onse Telecom } 12.7 \% \text {, SK Telink } \\
3.5 \% \text {, Special Service Providers } 26.3 \%\end{array}$ \\
\hline Broadband Internet & 3.6 & 7 & KT 53.4\%, Hanaro Telecom $27.1 \%$, Thrunet 10.5\% \\
\hline Mobile telecommunication & 16.0 & 3 & SK Telecom 59.7\%, KT Freetel 26.3\%, LG Telecom 10.9\% \\
\hline IMT-2000 & - & 3 & SK Telecom, KT Freetel, LG Telecom \\
\hline
\end{tabular}

Source: Ministry of Information and Communication.

58. Korea is relatively behind other member countries in local loop unbundling (LLU). In 2002, the MIC issued a public notification of unbundling requirements, standards and full implementation, which led to the opening and sharing of KT's copper line network and the broadband network of Internet service providers. However, a weak response led the MIC to revise the notification in 2003 by reducing fees and minimising access refusals. About 1000 loops were in use for LLU as of March 2004, and the number is expected to increase further.

59. The method for spectrum planning and allocation should be more competitive and transparent. Previously, MIC would provide information on the detailed allocation of spectrum bandwidths, select the operators and allocate the spectrum within the given bandwidth. For example, in the case of Broadband Wireless Local Loop (B-WLL), the MIC granted spectrum (which was later withdrawn) to KT and Hanaro Telecom without an open bidding procedure and without a contribution fee. Under a new approach, the MIC decides the number of operators for available bandwidths and announces the number of licenses to be issued and the application procedures. Licenses are allocated through a competitive tender procedure, socalled "beauty contests". For example, in 2001, three $3^{\text {rd }}$ generation (3G) licenses were sold for $\$ 2.9$ billion through beauty contests. While ten OECD countries have used beauty contests to allocate $3 \mathrm{G}$ licenses, fourteen used auctions, which generally achieved the objective of allocating licenses in a competitive and transparent manner (see OECD, 2003a).

60. Numbering policy is important in the context of enhancing local competition and reducing lockin effects. Not only do new entrants require adequate access to number resources to expand their services, but they also need to be assured that number portability will be allowed to support competition. For local calls, number portability will be extended to the entire country by 2004. As for mobile services, $2^{\text {nd }}$ generation $(2 \mathrm{G})$ number portability is being gradually introduced from January 2004 at six-month intervals, ${ }^{42}$ and $3^{\text {rd }}$ generation (3G $2 \mathrm{GHz}$ IMT-2000) number portability will be introduced within six months after the start of business by more than two service providers. Moreover, the identification numbers for the $2 \mathrm{G}$ and $3 \mathrm{G}$ phones will be gradually merged.

42. With an aim to assist the late entrants, mobile number portability will be introduced in three phases; SK Telecom in January 2004, KT Freetel in July 2004, and LG Telecom in January 2005. 
61. Current rate of return regulation on the tariffs of the dominant carriers, KT for local telephony and SK Telecom for mobile telephony, should be improved to promote competition and efficiency. The MIC has been exploring the introduction of a price cap on local telephony. By contrast, the rationale for imposing price controls on a cellular mobile company, which is rarely done in OECD countries, is not clear. The MIC justifies its regulation of SK Telecom's prices on the grounds that there are concerns about unfair pricing practices by the dominant firm. However, the need for any type of price control in the mobile sector should be re-considered, given that the market is competitive and prices are declining. The MIC has considered the introduction of a notification system in which tariffs filed by a carrier would take effect after a specified grace period, when they are judged not to pose any concerns for competition. However, in light of recent developments in the telecommunication industry and concerns over further market dominance, the MIC became more cautious about liberalising price regulations, and plans to maintain the current system until effective competition is established.

\section{Overall assessment and scope for further action}

62. The recommendations for strengthening competition are shown in Box 2. In summary, Korea has inherited a legacy of state intervention as a result of the government-led development strategy. The focus on creating world-class manufacturing industries, characterised by economies of scale, made competition a secondary consideration during much of its history. The economic reform process, which was accelerated by the 1997 crisis, is helping to reduce government intervention and regulation of the economy. The conflict between industrial development and competition, which still exists in the ministries responsible for network industries, should be resolved by the establishment of sectoral regulators that are independent of ministries. This process should continue by removing remaining entry barriers and further increasing openness to international trade and investment. At the same time, the KFTC should be strengthened and should focus on competition policy. Chaebol-regulating functions such as controlling internal crossholdings and guarantees and probing misuse of corporate assets that are related to finance and corporate governance should be concentrated in regulators responsible for financial and securities matters. Transactions that have an exclusionary or distorting effect on product market competition in particular cases should remain subject to competition-law control.

63. The scope for gains is large, given that labour productivity (per hour worked) in Korea is only about half of the OECD average. As the growth of factor inputs slows, increasing total factor productivity growth will become increasingly important in sustaining the convergence process. The gains are likely to be largest in the service sector, which currently faces more extensive regulation. Indeed, labour productivity in this sector is only 62 per cent of that in the manufacturing sector. One economic study found that reforms in five key sectors -- electricity, telecommunications, distribution, construction and road transport -- could boost GDP by 81/2 per cent (OECD, Regulatory Reform in Korea, 2000). 


\section{Box 2. Summary of recommendations to strengthen competition}

\section{Overall}

- Reduce entry barriers and regulations that limit competition.

\section{Promoting international competition}

- Reduce tariff levels and harmonise standards with international norms to avoid negative effects on imports.

- Lower the high level of agricultural protection to contribute to the success of multilateral trade negotiations, as well as facilitate Korea's participation in regional free trade agreements that would enable it to benefit from the economic dynamism of Asia.

- Establish conditions that will encourage inflows of foreign direct investment, in particular by bringing the economic framework into line with global standards and improving labour market conditions.

- $\quad$ Extend the special incentives in the Free Economic Zones to the rest of the country.

\section{Strengthen competition law}

- $\quad$ Grant the KFTC compulsory investigative powers to make its administrative enforcement more effective.

- Make the threat of individual sanctions more credible to ensure that it is an effective deterrent.

- Concentrate chaebol-regulating functions that are related to finance and corporate governance in regulators responsible for financial and securities matters. Transactions that have an exclusionary or distorting effect on product market competition in particular cases should remain subject to competition-law control.

- Eliminate remaining unnecessary special-interest exemptions, such as the small-business "cartels" for government procurement.

\section{Retail distribution}

- Deregulate zoning laws to facilitate the development of large retail outlets.

- $\quad$ Simplify the complex application process for opening large-size retail stores and make it more transparent. The arbitrary imposition of additional costs should be prevented.

\section{Professional services}

- Eliminate unnecessary constraints on entry and the form of practice in key professional sectors, particularly law and accounting.

- Abolish restrictions on competition, including fees, between members of the same profession, while encouraging competition between professional associations.

- Minimise the delegation of powers from the government to professional associations. They should not be granted exclusive jurisdiction to make decisions about entrance requirements and other issues.

\section{The electricity sector}

- Strengthen the government's commitment to a realistic reform programme that includes more detailed time schedules, while specifying the degree and method of privatisation of the generating and distributing subsidiaries, as well as the final market structure.

- Implement the plan to create independent generation and distribution companies to ensure that they do not have links to KEPCO, which will run the transmission system, nor significant common ownership.

- $\quad$ Ensure cost-reflective pricing, such as a price-cap system, and eliminate cross subsidisation between sectors to provide incentives for the efficient use of electricity.

- Establish an independent regulator. Given MOCIE's policy and industry promotion responsibilities in the electricity sector, and its role as "owner" in voting the government's shares in KEPCO, it will be important that MOCIE play no direct regulatory role. 
- Strengthen competition law enforcement in the energy sector, particularly with respect to market access and anticompetitive conduct, by enhancing co-operation between the sector regulator and the KFTC.

\section{The natural gas sector}

- Establish a firm timetable for reform in order to prevent further uncertainty and delay, while balancing the goal of introducing competition with concerns about the security of energy and KOGAS's existing contracts with LNG producers.

- $\quad$ Provide incentives for efficient use of gas by ensuring cost-reflective pricing such as a price-cap system.

- Establish an independent regulator and separate it from the policy functions to be retained by MOCIE. Strengthen competition law enforcement in the energy sector by increasing co-operation with the KFTC.

The telecommunication sector

- Use auctions to allocate spectrum for all wireless licences.

- Impose a price cap system in markets where KT remains dominant, while refraining from interfering in all other markets.

- $\quad$ Take more comprehensive measures to promote competition in the local loop.

- Transform the KCC into an independent communications sector regulator, clearly differentiating MIC's policy responsibilities from regulatory responsibilities.

- $\quad$ Reduce barriers to entry by introducing a general approval system.

- Implement number portability extensively to minimise the transaction costs of changing service provider. 


\section{BIBLIOGRAPHY}

Cho, Dongchul and Hyeon Park (2003), "Economic Impact of the Construction of a New Capital", 2003 Annual Report, Korea Development Institute, Seoul (in Korean).

Han, Chin Hee et al. (2002), "Prospects for the Korean Economy's Potential Growth Rate: 2003 to 2012", Korea Development Institute Policy Study 2002-07, Seoul (in Korean).

IEA (2002a), Energy Policies of IEA Countries: The Republic of Korea 2002 Review, Paris.

IEA (2002b), Flexibility in Natural Gas Supply and Demand, Paris.

IEA (2003), Energy Prices \& Taxes: Quarterly Statistics, Paris.

Jeong, Kap-Young et al. (2002), "Mid-\&-Long-Term Vision of Competition Policies: Competition 2010", Korea Academic Society of Industrial Organization, Seoul, mimeo (in Korean).

Jung, Hee-Nam (2003), "Strategy for the Reform of Land-Use Regulations", Korea Research Institute for Human Settlements, Seoul (in Korean).

Kalirajan, K. (2000), "Restrictions on Trade in Distribution Services", Staff Research Paper, Productivity Commission, Ausinfo, Canberra.

Kim, Dong-Whan (2003), "Deregulation for Productivity in the Distribution Sector", Korea Chamber of Commerce \& Industry, Seoul, mimeo (in Korean).

Kim, Jaehong (2002), "Entry Regulation: Theory and Practice”, Korea Economic Research Institute, Seoul (in Korean).

Kim, Wan-Soon and Michael Jae Choo (2002), "Managing the Road to Globalisation: The Korean Experience", Korea Trade-Investment Promotion Agency (KOTRA), Seoul.

Korea Development Institute (1997), "Moving toward a Competitive Market Structure", Seoul, mimeo (in Korean).

Lee, Jae-hyung (2002), “Analysis of Market Concentration in Korea: Mining and Manufacturing Sectors”, Korea Development Institute Policy Study 2002-10, Seoul (in Korean).

McKinsey \& Company (1998), "Productivity-led Growth for Korea: General Merchandise Retail Industry", Seoul and Washington.

Nam, Il-Chong et al. (2001), "Reforming tariff regulation in privatized network industries", Korea Development Institute, Seoul, mimeo (in Korean).

Nguyen-Hong, D. (2000), "Restrictions on Trade in Professional Services", Staff Research Paper, Productivity Commission, Ausinfo, Canberra. 
OECD (1999), Economic Survey of Korea, Paris.

OECD (2000a), Economic Survey of Korea, Paris.

OECD (2000b), Regulatory Reform in Korea, Paris.

OECD (2000c), Regulatory Reform in Road Freight and Retail Distribution, Paris.

OECD (2001a), Economic Survey of Korea, Paris.

OECD (2001b), OECD Economic Studies, Special Issue: Regulatory Reform, No. 32, Paris.

OECD (2002), "Product Market Competition and Economic Performance", OECD Economic Outlook, No. 72, December, Paris.

OECD (2003a), After the Telecommunications Bubble, Paris.

OECD (2003b), Communications Outlook, Paris.

OECD (2003c), Economic Survey of Korea, Paris.

OECD (2004), Economic Survey of Japan, Paris.

Office of Ministry for Trade (2003), Review of EUCCK's Trade Issues \& Recommendations 2003, Seoul.

Suh Yong-Ku, et al. (2002), "Economic Effects of Structural Changes in the Distribution Industry", Research Paper submitted to MOCIE, Sookmyung Women's University, Seoul (in Korean). 


\section{WORKING PAPERS}

The full series of Economics Department Working Papers can be consulted at www.oecd.org/eco/Working_Papers/

398. Product Market Competition and Economic Performance in the United States (July 2004) Hannes Suppanz, Michael Wise and Michael Kiley

397. Saving Behaviour and the Effectiveness of Fiscal Policy (July 2004) Luiz de Mello, Per Mathis Kongsrud and Robert Price

396. The impact of exchange rate regimes on real exchange rates in South America, 1990-2002 (June 2004) Anne-Laure Baldi and Nanno Mulder

395. How Market Imperfections and Trade Barriers Shape Specialisation: South America vs. OECD (June 2004) Joaquim Oliveira Martins and Tristan Price

394. Housing Markets, Wealth and the Business Cycle (June 2004) Pietro Catte, Nathalie Girouard, Robert Price and Christophe André

393. Long-Term Budgetary Implications of Tax-Favoured Retirement Saving Plans (June 2004) Pablo Antolin, Alain de Serres and Christine de la Maisonneuve

392. Enhancing Income Convergence in Central Europe after EU Accession (June 2004) Patrick Lenain and Lukasz Rawdanowicz

391. Asset Price Cycles, “One-Off” Factors and Structural Budget Balances (June 2004) Nathalie Girouard and Robert Price

390. Channels for Narrowing the US Current Account Deficit and Implications for Other Economies (May 2004) Anne-Marie Brook, Franck Sédillot and Patrice Ollivaud

389. Product Market Competition and Economic Performance in Norway (May 2004) Jens Høj and Michael Wise.

388. Product Market Competition and Economic Performance in Sweden (May 2004) Deborah Roseveare, Martin Jørgensen and Lennart Goranson

387. Product Market Competition and Economic Performance in Japan (May 2004) Jens Høj and Michael Wise

386. Migration and Integration of Immigrants in Denmark (May 2004) Deborah Roseveare and Martin Jørgensen

385. Factors Driving Risk Premia (April 2004) Torsten Sløk and Mike Kennedy

384. Rationalising Public Expenditure in the Slovak Republic (March 2004) Rauf Gönenç and Peter Walkenhorst

383. Product Market Competition and Economic Performance in Switzerland (March 2004) Claude Giorno, Miguel Jimenez and Philippe Gugler

383. Concurrence sur les Marchés de Produits et Performance Économique en Suisse (Mars 2004) Claude Giorno, Miguel Jimenez and Philippe Gugler 
382. Differences in Resilience between the Euro-Area and US Economies (March 2004) Aaron Drew, Mike Kennedy and Torsten Sløk

381. Product Market Competition and Economic Performance in Hungary (March 2004) Carl Gjersem, Philip Hemmings and Andreas Reindl

380. Enhancing the Effectiveness of Public Spending: Experience in OECD Countries (February 2004) Isabelle Joumard, Per Mathis Kongsrud, Young-Sook Nam and Robert Price

379. Is there a Change in the Trade-Off between Output and Inflation at Low or Stable Inflation Rates? Some Evidence in the Case of Japan

(February 2004) Annabelle Mourougane and Hideyuki Ibaragi

378. Policies bearing on product market competition and growth in Europe (January 2004) Carl Gjersem

377. Reforming the Public Expenditure System in Korea (December 2003) Young-Sook Nam and Randall Jones

376. Female Labour Force Participation: Past Trends and Main Determinants in OECD Countries (December 2003) Florence Jaumotte

375. Fiscal Relations Across Government Levels (December 2003) Isabelle Joumard and Per Mathis Kongsrud

374. Health-Care Systems: Lessons from the Reform Experience (December 2003) Elizabeth Docteur and Howard Oxley

373. Non-Tariff Measures Affecting EU Exports: Evidence from a Complaints-Inventory (December 2003) Peter Walkenhorst and Barbara Fliess

372. The OECD Medium-Term Reference Scenario: Economic Outlook No. 74 (November 2003) Peter Downes, Aaron Drew and Patrice Ollivaud

371. Coping with Ageing: A Dynamic Approach to Quantify the Impact of Alternative Policy Options on Future Labour Supply in OECD Countries

(November 2003) Jean-Marc Burniaux, Romain Duval and Florence Jaumotte

370. The Retirement Effects of Old-Age Pension and Early Retirement Schemes in OECD Countries (November 2003) Romain Duval

369. Policies for an Ageing Society: Recent Measures and Areas for Further Reform (November 2003) Bernard Casey, Howard Oxley, Edward Whitehouse, Pablo Antolin, Romain Duval, Willi Leibfritz

368. Financial Market Integration in the Euro Area (October 2003) Carl Gjersem

367. Recent and Prospective Trends in Real Long-Term Interest Rates: Fiscal Policy and Other Drivers (September 2003) Anne-Marie Brook

366. Consolidating Germany's finances: Issues in public sector spending reform (September 2003) Eckhard Wurzel

365. Corporate Taxation of Foreign Direct Investment Income 1991-2001 (August 20030) Kwang-Yeol Yoo 
ECO/WKP(2004)22 